1

2

3

4

\title{
HYDROLOGICAL BEHAVIOR OF A DEEP SUB-VERTICAL FAULT IN CRYSTALLINE BASEMENT AND RELATIONSHIPS WITH SURROUNDING RESERVOIRS
}

C. ROQUES*(1), O. BOUR(1), L. AQUILINA(1), B. DEWANDEL(2), S. LERAY(1), JM. SCHROETTER(3), L. LONGUEVERGNE(1), T. LE BORGNE(1), R. HOCHREUTENER(1), T. LABASQUE(1), N. LAVENANT(1), V. VERGNAUD-AYRAUD(1), B. MOUGIN(3)

(1) Université Rennes 1-CNRS, OSUR-Géosciences Rennes, avenue du Général Leclerc, 35000 Rennes, France

(2) BRGM, Water Dept., New Water Resource \& Economy Unit, 1039, Rue de Pinville, 34000 Montpellier, France

(3) BRGM, French Regional Geological Survey of French Brittany, Rennes Atalante Beaulieu 2 rue de Jouanet, 35700 Rennes, France

* Corresponding author: Clément Roques, Université Rennes 1 - CNRS, OSUR Géosciences Rennes, 263 avenue du Général Leclerc, 35000 Rennes, France.

Email: clement.roques@univ-rennes1.fr

Phone: (0033)2.23.23.54.69.

Fax: (0033)2.23.23.60.90. 
19

20

21

22

23

\section{ABSTRACT}

Crystalline-rock aquifers generally yield limited groundwater resources. However, some highly productive aquifers may be encountered, typically near tectonic discontinuities. In this study, we used a multidisciplinary experimental field approach to investigate the hydrogeological behavior of a sub-vertical permeable fault zone identified by lineament mapping. We particularly focused our investigations on the hydrogeological interactions with neighboring reservoirs.

The geometry of the permeable domains was identified from geological information and hydraulic test interpretations. The system was characterized under natural conditions and during a 9-week large-scale pumping test. We used a combination of piezometric analysis, flow logs, groundwater dating and tracer tests to describe the interactions between permeable domains and the general hydrodynamical behaviors.

A clear vertical compartmentalization and a strong spatial heterogeneity of permeability are highlighted. Under ambient conditions, the vertical permeable fault zone allows discharge of deep groundwater flows within the superficial permeable domain. The estimated flow across the total length of the fault zone ranged from 170 to $200 \mathrm{~m}^{3} /$ day. Under pumping conditions, hydrological data and groundwater dating clearly indicated a flow inversion. The fault zone appears to be highly dependent on the surrounding reservoirs which mainly ensure its recharge. Groundwater fluxes were estimated from tracer tests interpretation. This study demonstrates the hydrogeological capacities of a sub-vertical fault aquifer in a crystalline context. By describing the hydrological behavior of a fault zone, this study provides important constrain about groundwater management and protection of such resources.

Keywords: Hydrogeology, crystalline rocks, lineament, fault zone, large scale pumping test, sustainable groundwater resource. 


\section{$43 \quad 1$ INTRODUCTION}

44 Crystalline rocks cover large areas throughout the world of about $35 \%$ of the continental surface

45 (Amiotte Suchet et al., 2003; Blatt and Jones, 1975) and may constitute a crucial water resource for 46 vast population. The porosity and permeability of primary crystalline rocks are extremely low, but 47 their hydraulic properties can be greatly modified as a result of secondary physical processes (unloading, tectonic activities...) and/or geochemical processes such as weathering, fluid circulation (Bahat, 1999; Caine et al., 1996; Evans et al., 1997; Henriksen and Braathen, 2005; Taylor and Howard, 2002, 1999)... Various conceptual models of hydrogeological compartmentalization in crystalline rock aquifers have been proposed (Chilton and Foster, 1995; Dewandel et al., 2006; Maréchal and Wyns, 2004; Taylor and Howard, 1999; Wyns et al., 2004). They usually consist of two main reservoirs: 1$)$ a layer of alterites ( $<15$ meters bgs), identified as a specific reservoir with a relatively high porosity and storage, highly sensitive to rainfall recharge; 2 ) a superficial fractured zone, of various thickness and which may be characterized by relatively dense sub-horizontal and sub-vertical fracturing. This fractured reservoir has in general a higher permeability although well yields are typically limited to less than $10 \mathrm{~m}^{3} / \mathrm{h}$.

However, highly productive zones have been locally highlighted in regions exposed to past or current tectonic activity, such as Brittany. In practice, although controversial (Gleeson and Novakowski, 2009), hydrogeologists often use fracture outcropping analysis or "lineaments" mapping to determine drilling localization, especially when such lineaments result from extensive tectonic activity (Gleeson and Novakowski, 2009; Henriksen and Braathen, 2005; Sander, 2006; Singhal and Gupta, 2010). Many factors must be considered to ensure the viability of the resource such as rock lithology affected by tectonic activity, stress fields and intensity of deformation. Such factors and fluid flow processes determine fault zone permeability (Caine et al., 1996; Evans et al., 1997; Gleeson and Novakowski, 2009; Goddard and Evans, 1995). Few hydrogeological studies examined relationships between lineaments structures, hydrogeological flow organization and productivity 
wells (Fernandes and Rudolph, 2001; Henriksen and Braathen, 2005; Holland and Witthüser, 2011; Richard et al., 2002; Sander, 2006). Fault zones may act as conduits, barriers, or as combined conduit-barrier systems that enhance or impede fluid flow (Bense and Person, 2006; Caine et al., 1996) but can also significantly influence groundwater flow, spring discharge, and water-table elevations (Apaydin, 2010; Gleeson and Novakowski, 2009; Melchiorre et al., 1999).

In some cases, aquifers near highly conductive fault zones and with relatively high production rates for crystalline rocks (from 20 to $100 \mathrm{~m}^{3} / \mathrm{h}$ ) have been described: Ploemeur aquifer, Brittany (Le Borgne et al., 2006a; Leray et al., 2013; Ruelleu et al., 2010), the New Hampshire Bedrock Aquifer (Richard et al., 2002), Crystalline Rock Aquifers in New England (Harte et al., 2008) and in the Limpopo Province of South Africa (Holland and Witthüser, 2011).

The hydrodynamic functioning of fault structures in various geological contexts has been investigated in several studies. In sedimentary media, Bense et al. $(2006 ; 2003)$ showed the important effects of the geometry and anisotropy of a fault zone on its hydraulic properties. Numerical studies, such as those by Anderson et al. (Anderson and Bakker, 2008), also highlighted the influence of a vertical fault on groundwater flow. In the crystalline context, some studies have described the permeability architecture and hydrogeological functioning of fault zones for groundwater resources (Boutt et al., 2010; Caine and Tomusiak, 2003; Evans et al., 1997; Ganerod et al., 2008; Stober and Bucher, 1999) or hydrocarbon entrapment (Aydin, 2000). However, very few studies have analyzed the hydrological functioning of faults in a water abstraction context. In this context, aquifer yields will mainly depend on the ability of interactions between the fault and the surrounding reservoirs to allow recharge and water availability. On the other hand, groundwater abstraction from a deep resource will undoubtedly modify the hydrodynamic gradients and lead to mixing between the different reservoirs. The hydrogeological influence of deep fault zones on overlaying reservoirs is poorly known and is apparently difficult to characterize by field studies (Banwart et al., 1994; Carucci et al., 2012; Folch and Mas-Pla, 2008; Gannon et al., 2011; Sophocleous, 2002). This question has been 
93

94

tackled out only through few numerical studies, which have reported the hydrological efficiency of fault zones to act as preferential flow zone that enhances recharge processes from surrounding reservoirs (Folch and Mas-Pla, 2008; Leray et al., 2013).

The first aim of this study is to characterize the hydrodynamic functioning of a sub-vertical permeable fault zone in crystalline basement from a large-scale field experiment. The main objectives are to i)describe the architecture of the aquifer system, ii) define the flow organization between the permeable zones and recharge processes towards the deep fault zone under natural and pumping conditions and iii) characterize the origin of groundwater and mixing processes due to groundwater abstraction. The experiment is carried out on a specific field site in Brittany (Western France), identified by lineament observation (Carn-Dheilly and Thomas, 2008), where a permeable fault zone at more than 100 meters depth is able to provide about $100 \mathrm{~m}^{3} / \mathrm{h}$ according to air-lift flow measurements.

We first describe the characteristics of the groundwater system under ambient conditions to highlight the hydrologic functioning of deep structures at the catchment scale. We then describe a 9week large-scale pumping test that was carried out to identify the hydraulic properties of the aquifer system. During this test, various complementary experiments and measurements were conducted to investigate flow interactions between the different reservoirs and to identify mixing processes. Finally, the combined analyses from this multidisciplinary experiment are used to develop a hydrogeological conceptual model of a sub-vertical fault zone in crystalline context.

\section{GEOLOGICAL AND HYDROGEOLOGICAL SETTING}

The experimental site of Saint-Brice en Coglès is located in the Mancellian Domain of the "Massif Armoricain", in Brittany (France), where it constitutes the north western French part of the Cadomian and Variscan orogenies ((Figure 1a). This formation outcrops from western to central Europe and is mainly composed of low to high grade (migmatite) metamorphic rocks, with regional- 
117 scale magmatic intrusions (Cadomian granodiorites). The Mancellian Domain is limited in the north

118 by the English Channel, and to the south by the North Armorican Shear Zone (NASZ). The main

119 lithologies encountered are Precambrian (Brioverian) sedimentary rocks ((Figure 1a), composed of 120 alternating series of argillites/siltites and sandstones. These sedimentary rocks have been affected by

121 low grade metamorphism which has formed a metamorphic aureole around the Cadomian

122 granodiorites on a regional-scale (Ballèvre et al., 2009; Brun et al., 2001; Chantraine et al., 2001;

123 Cogné and Wright, 1980). The most important deformation zone corresponds to a major ESE-WNW

124 dextral strike-slip shear zone, the NASZ attributed to hercynian orogeny. Secondary SW-NE reverse

125 faults are also found around this main shear zone. These terrains have been affected by Pyrenean

126 and Alpine orogenies that have generated a diffuse deformation characterized by half-graben basins

127 (Rennes basin, Landéan basin...) and NW-SE sub-vertical faults (Grellet et al., 1993; Van Vliet-Lanoë et

128 al., 1997).

The Saint-Brice en Coglès site is located in the epimetamorphism zone of a large Cadomian pluton

130 (Fougère granite). The rocks consist of Brioverian sediments metamorphosed into hornfels schists.

131 The vicinity of the site is characterized by parallel extensional N-S normal faults that form localized

(Figure 1)

Local geological structures were imaged by carrying out a structural analysis including landscape, geological mapping and geophysical (electric and seismic tomographies) analysis. Sub-vertical faults and extensional graben structures were clearly identified ((Figure 2a). In addition, three deep boreholes (MFT20, MFT80 and, F3) were drilled using "Down Hole Air Hammer" drilling method. Another deep borehole (FC4, $250 \mathrm{~m}$ ), which has been entirely cored, has been drilled along a profile perpendicular to the orientation of the main accident lineament (Figure 2b). The borehole characteristics are detailed in (Table 1. Several shallow boreholes (labeled T in (Figure 2b) were also 
142 weathered material with high clay and sand contents. Examination of the cores revealed that the

143 Brioverian rocks were highly deformed and fractured, and intruded by metric aplites, pegmatites and 144 quartz veins, oriented $\mathrm{N} 50^{\circ}$ to $\mathrm{N} 70^{\circ}$. Particularly, in the vicinity of the fault outcropping, the 145 Brioverian rocks are affected by horizontal fractures, characterized by a density decrease with depth, to an average of about 40-50 meters. The main fault zone was identified in each borehole as a highly fractured and productive zone, ranging from a few meters thick (see core sampling in (Figure 2c) to $15 \mathrm{~m}$ in the outcropping part of the borehole ((Table 1 and (Table 2$)$. The fault typically dips by $70^{\circ}$ to the NNW ((Figure 2c). Wells were completed with a slotted casing in the deep productive zones.

(Figure 2)

(Table 1)

\section{MATERIAL AND METHODS}

\section{$153 \quad 3.1$ FIELD EXPERIMENT}

The interactions between the fault zone and the other hydrologic domains were described and quantified by investigating the site under natural conditions and during a large-scale pumping test. A packer was placed $80 \mathrm{~m}$ below the ground surface in borehole F3 to ensure that pumping was carried out deep within the fault zone. As a result, water abstraction occurred principally from the fault zone at 110 meters below ground surface ((Table 1). Pumping lasted for two months (63 days) at a flow rate of about $45 \mathrm{~m}^{3} / \mathrm{h}$. During the pumping test, total rainfall was limited to $40 \mathrm{~mm}$, and potential evapotranspiration was 90 mm (information available from Saint Mars-sur-la-Futaie weather station$48^{\circ} 26^{\prime} \mathrm{N} 0^{\circ} 58^{\prime} \mathrm{W}, 30 \mathrm{~km}$ north-east of the Saint-Brice site). Complementary experiments and analyses carried out are described in the following. 
164 Water levels were recorded using a pressure sensor with barometric compensation (STSC) and

165 Schlumberger (C) pressure transmitters). The altitude of the well was determined by differential GPS.

166 The estimated uncertainty for the absolute water level measurements was about a centimeter. The

167 mean hydraulic parameters of the system under pumping conditions were determined from classic analytical models. In addition, a logarithmic derivative method of drawdown measurement was used to analyze flow regimes (Bourdet and Ayoub, 1989; Renard et al., 2008; Spane and Wurstner, 1993).

This method also permitted identification of flow behaviors and an estimation of the system's transmissivity based on Cooper and Jacob's approximation (Renard et al., 2008).

\subsection{HIGH RESOLUTION FLOW AND TEMPERATURE LOGGING}

Structural heterogeneity of fractured rocks induces flow partitioning within the aquifer system. To examine preferential flow path and fracture connectivity we used high-resolution flow logging (Heat Pulse Flowmeter, Geovista(C) under ambient and pumping conditions (Le Borgne et al., 2006b; Paillet, 1998). Single-borehole flowmeter tests provide information on the main inflow or outflow zones in a well and measure the prevailing ambient flow conditions in the absence of pumping (Le Borgne et al., 2006b; Paillet, 1998). During a pumping test, cross-borehole flowmeter tests (pumping in a given well and measurement in another) are based on the observation that transient flow during pumping in a given aquifer modifies the hydraulic head distribution with time in the different permeable domains and produces measurable changes in the vertical flow profiles. The connectivity and hydraulic properties of the main flow paths can be identified by transitory flow measurements (Le Borgne et al., 2006b; Paillet, 1998).

To define flow paths and origin of the water, temperature logging was also used with a multiparameter Hydrolab probe (OTTC) and Ocean seven 303 CTD (Idronaut@). Differences in hydraulic heads between the fractures in a borehole, under ambient conditions or during pumping, will modify the temperature profile with respect to the geothermic gradient. Therefore these temperature 
188

189

190

191

192

193

194

profiles are very useful to identify hydraulic connections between compartments and their evolution through time (Anderson, 2005; Bense et al., 2008; Chatelier et al., 2011).

\subsection{TRACER TESTS}

To identify transfer time distribution and to characterize groundwater flows within the main transmissive fault zone, tracer tests were performed between observation wells and the pumped borehole. Tracer breakthrough concentrations were monitored in the pumped well (F3) within the upper casing and below the pump with a flow-through field fluorometer developed by the University of Neuchâtel (Schnegg and Costa, 2007; Schnegg and Flynn, 2002). The fluorometers had been previously calibrated with tracer and local fresh water in the laboratory. To optimize injection, we identified the main fractured part of the fault zone connected to the pumped well (F3) in each observation wells (MFT80 and FC4). Uranine tracer solution was injected in front of the main inflow zone and we checked that no tracer solution remained in the borehole after the injection by logging concentration through borehole depth.

\subsection{GEOCHEMISTRY AND GROUNDWATER DATING}

To identify water origin and estimate mixing processes, we analyzed geochemistry and groundwater dating data under ambient and pumping conditions. The apparent ages of water samples were determined by measuring Chlorofluorocarbons (CFCs) concentrations. These anthropogenic gases provide information on groundwater resident times up to 50 years and can give information on mixing processes between different water sources during flow changes (Ayraud et al., 2008; Busenberg and Plummer, 1992; Cook and Solomon, 1997; Cook et al., 2005; Jaunat et al., 2012). Waters were sampled in stainless-steel ampoules after discarding at least three ampoule volumes, and ensuring that there was no contact of the water with atmospheric gases.

Groundwater CFCs concentrations were measured by the Geosciences Rennes Laboratory (Labasque, 2006). Water samples were degassed by N2 stripping and then injected into a gas chromatograph 
212 equipped with an electron capture detector (GC-ECD). The CFC concentration obtained by 213 chromatographic analysis was converted to the atmospheric mixing ratio (pptv - Parts per Trillion by

214 Volume) by applying a solubility function (modified Henry's Law for trace gases (Ayraud et al., 2008; 215 Bu and Warner, 1995; Warner and Weiss, 1985; Weiss and Price, 1980)). The CFC atmospheric mixing ratios were then compared with the atmospheric evolution curve (Walker et al., 2000) to determine the apparent recharge year, and thus the apparent age of the groundwater. Analytical uncertainty for the CFC concentrations was estimated (Labasque, 2006) at around $3 \%$ for recent water (<20 years) and $5 \%$ for old water (between 55 to 30 years).

Major and trace elements were analyzed by ion chromatography (Dionex DX-100) and ICP-MS HP 4500 at the Geosciences Rennes Laboratory following standard laboratory methods. The analytical uncertainty for major anions and cations was about $2 \%$.

\section{RESULTS}

\subsection{AMBIENT FLOW CONDITION}

(Figure 3 shows the evolution of hydraulic head in the main boreholes representative of the fractured domains (FC4, F3, MFT80 and MFT20) and in the upper weathered reservoir $\left(T_{i}\right)$. The seasonal evolution of hydraulic head is similar in all the aquifer system with a fast response to rainfall during the recharge periods and a classic discharge regime observed during summer.

229 The hydraulic head gradient mostly follows the topography and indicates groundwater flow towards

230 the outcropping of the fault zone and discharge into the river (FC4-F3-MFT80 in (Figure 2b\&c).

231 Measurements of the hydraulic gradient with depth revealed a higher hydraulic head in the deeper boreholes ((Figure 3). This suggests a definite vertical compartmentalization of the aquifer system. The three boreholes intersecting the permeable fault zone show similar hydraulic responses, with a 
235

236

237

edge of the weathered and the fractured bed rock, remains under the influence of the fault zone. The sub-surface aquifer situated within the upper weathered part ( $T_{i}$ boreholes), appears to be much less influenced by the deep structure.

The fault domain responds quickly to rainfall even though it is locally covered by the sub-surface reservoir with lower hydraulic head. This suggests that the bed rock domain can respond rapidly to recharge. The recharge area is certainly along strike and up topographic gradient through favorable deep fractured zones.

\section{(Figure 3)}

A typical variation of flow rate with depth is shown in (Figure 4. All flow profiles obtained under ambient conditions reveal upward flow, implying that hydraulic head is higher in the deep fractures ( $235 \mathrm{~m}$ for FC4) than in the upper fractures ( $45 \mathrm{~m}$ for FC4). FC4 profile in ambient conditions show a major inflow zone at $245 \mathrm{~m}$ deep and a major outflow zone at $49 \mathrm{~m}$ deep (Figure 4). No other contributing fractures can be detected, either because of the limit of detection of the tool, or simply because of the lack of any hydraulic head gradient between the head in the fractures and the head in the borehole. In pumping conditions, and for a much lower hydraulic head in the borehole, few others fracture may be detected between 160 and 215 meters deep. In any case, the flow rate profiles obtained under pumping conditions confirms that the deep conductive fault zone provides about 50 to $75 \%$ of the total productivity of each borehole ((Table 2). For all profiles, the fracture transmissivity was determined by using the model developed by Paillet (1998). The transmissivity of the deep productive sections in each well appeared to be relatively high, ranging between 6 and $9 x$ $10^{-4} \mathrm{~m}^{2} / \mathrm{s}$ ((Table 2).

\section{(Table 2)}

Groundwater dating by CFCs analyses also highlighted the influence of an old deep water origin, with tracer concentrations close to the detection limit in all deep boreholes ((Table 3), including the $20 \mathrm{~m}$ 
259

260

261

262

263

264

265

266

267

268

269

270

271

272

273

274

275

276

277

278

280

281

depth well. The apparent water age is older than 55 years. Conversely, CFCs analyses in the first $10 \mathrm{~m}$ of the weathered domain revealed recent waters and contamination with nitrate. Globally, the apparent age determined in the upper weathered reservoir and based on a piston flow model, is 20 years. Moreover, the water age in this upper part of the aquifer system decrease uphill. This suggests that the subsurface aquifer is partially influenced by deep groundwater discharge (more or less $25 \%$ of old deep water).

\section{(Table 3)}

To summarize, three main hydraulic domains were highlighted at the Saint-Brice site: (1) the fault zone which has a higher transmissivity, (2) the surrounding domain affected by secondary fractures less transmissive and (3) the upper weathered part of the aquifer system, restricted to the first 10 meters. Under ambient conditions, the hydrogeological system is clearly driven by the discharge from a deep groundwater system towards the upper part of the aquifer system and the local stream.

\section{(Figure 4)}

\subsection{PUMPING CONDITION}

\subsubsection{EVOLUTION OF HYDRAULIC HEADS AND DIAGNOSTIC PLOT}

During the 60-days pumping experiment, the hydraulic heads in the different boreholes were recorded ((Figure 5). All wells located in or near the sub-vertical fault zone, including the shallow piezometers in the sub-surface weathered domain, reacted quickly to pumping. During the first 10 days, drawdown was limited to a few meters and was similar in all boreholes. This suggests a good connection between the upper and lower domains of the aquifer system. After 10 days of pumping, drawdown has exceeded the depth of the sub-surface wells ( $<10 \mathrm{~m}$ deep), due to desaturation of the upper weathered reservoir around the pumping well. As observed in all deep boreholes, drawdown increased significantly during the last 50 days of pumping ((Figure 5).

\section{2 (Figure 5)}


283

284

285

286

287

288

289

290

291

292

293

294

295

296

297

298

299

300

301

302

303

304

305

306

307

Figure 6 displays the normalized drawdown (s/Q) of pumping well F3 and its derivative through time in a log-log diagram. The evolution of the derivative curve provides information on flow behaviors and on boreholes effects such as wellbore storage and skyn effects. Such diagnostic curves can be used to interpret different flow regimes (Bourdet et al., 1983; Renard et al., 2008), e.g. double porosity, leakage effect, no-flows boundaries... Here, considering the specific geometry of the aquifer system, we assumed that flow regimes can be described through a simple model developed for fracture or strip aquifer embedded in lower permeable block (Butler and Liu, 1991; Escobar and Hernández, 2010; Gringarten, 1996; Moench, 1984; Rafini and Larocque, 2009; Tiab, 2005). Such fracture models involve generally three characteristic flow regimes: the early local response of the fault zone, a period of transition controlled by the geometrical fault zone properties at larger scale and finally the global hydraulic response of the system.

Flow behaviors can be detailed as follow through derivative description: ((Figure 6). 1) After the first early-time where the drawdown response is influenced by wellbore storage and skin effects, a short radial flow response is observed. This reflects the behavior of the local permeable fault zone, where water was principally extracted from the local fracture storage and eventually fed by proximal matrix storage and/or local leakage from overlaying aquifers. The constant derivative value suggests a transmissivity around $10^{-3} \mathrm{~m}^{2} \cdot \mathrm{s}^{-1}$. The derivative decrease between 0.1 and 1 day can be the consequence of preferential leaky flows from shallower reservoir. 2) Between 1 to 30 days of pumping, the drawdown derivative curve is characterized by a transitory period with a strong increase (derivative slope of $1 / 2$ ). This derivative increase can be interpreted as double porosity behavior for which lateral inflows from surrounding reservoirs supply the permeable fault at larger scale. The fault geometry can also influence the drawdown during this transitory period which induces linear flow regime. 3) Finally, the system reached a radial flow condition during the last month of pumping, where the whole system was solicited indicating that the major flow comes from surrounding low-permeability domains (Butler and Liu, 1991). The normalized constant derivative of 
308

309

310

311

312

313

314

315

316

318

320

321

322

323

324

325

326

327

$0.18 \mathrm{~m}$ at the end of the test implies a global transmissivity of the aquifer system about $10^{-4} \mathrm{~m}^{2} \cdot \mathrm{s}^{-1}$

\section{(Figure 6)}

\subsubsection{FloWmEter teSt AND teMPERATURE LOGgING}

Flow and temperature logs under natural and pumping conditions are presented for MFT80 in (Figure 7. Other observation wells yielded similar results. Under ambient conditions, upward flows were identified ((Figure $\left.7 \mathrm{a}_{1}\right)$, implying that the hydraulic head in the deeper part of the fault zone was higher than in the upper part of the aquifer domain. During pumping, downward flows were measured, indicating a greater decrease of the hydraulic head in the fault zone. Downward flow could be even 3 times greater than the previous upward flow, which implied a clear inversion of flow between the hydraulic permeable domains ((Figure $\left.7 b_{1}\right)$. Nevertheless, the downward borehole flows slowed down after a few days, in conjunction with the decrease in head gradient between the two compartments ((Figure $\left.7 c_{1}\right)$.

Temperature logs ((Figure $\left.7_{2}\right)$, carried out under ambient conditions and during pumping in all observation wells, showed a clear temperature decrease of about 0.2 to $1^{\circ} \mathrm{C}$ with pumping. The homogeneity of the profiles, with lower temperatures than under ambient conditions, suggests that the deep aquifer domain was fed by colder water coming from the sub-surface domain ((Figure $7 b_{2}$ and $c_{2}$ ). This confirms that pumping is initiated within the fault zone at depth and that the upper aquifer domain is supplying the deeper structure.

\section{(Figure 7)}

\subsubsection{PUMPING TEST MODELING}

The hydraulic parameters of the aquifer system were evaluated by fitting the drawdown data with classic analytical models. Different solutions were applied to interpret the dataset at different times ((Figure 8). in view to characterize the two main flow behaviors involved during the test, previously 
332

333

334

characterized by the derivative interpretation: 1) the fault storage response, supported by leaky flow from the weathered part of the aquifer system ( $<10$ days of pumping) and 2 ) the global double porosity response of the aquifer system during long term pumping.

For the first 10 days of pumping, the double porosity analytical solution according to Moench's model (Moench, 1984) was used to model the local fault zone response. This model is based on the concept of a fracture embedded within blocks of lower permeability, characterized by matrix storage. Solutions are presented in equations 19 and 20 from the Moench paper of 1984 and plotted for the early time in MFT80 for both drawdown and its derivative in (Figure 8a. Quadratic head losses were estimated by a variable rate pumping test at $2.510^{4} \mathrm{~m}^{-5} \mathrm{~s}^{2}$. Hydraulic parameters deduced from all wells are listed in (Table 4. These parameters confirm that, during the first days of pumping, flow is controlled by a relatively high transmissive $\left(T 1=7 \cdot 10^{-4} \mathrm{~m}^{2} \cdot \mathrm{s}^{-1}\right)$ fault zone embedded in lower permeability blocks $\left(K b=2 \cdot 10^{-8} \mathrm{~m} \cdot \mathrm{s}^{-1}\right)$. A strong fracture skin value (set to 1 ) was required to model the first times of both drawdown and derivative, which suggest a strong delay contribution between surrounding blocks to the fractured zone (Moench, 1984).

\section{(Table 4)}

We also used the "Two Aquifer-System" model developed by Hunt and Scott (2007) to characterize drainage flows from weathered reservoir to the fractured domain. This model assumes a screened well in an aquifer overlain by an aquitard and an unconfined aquifer which may represent here the upper weathered reservoir. A mean transmissivity of $T 1=5 \cdot 10^{-4} \mathrm{~m}^{2} \cdot \mathrm{s}^{-1}$ for the deeper aquifer domain, and transmissivity and porosity estimates of $6.10^{-5} \mathrm{~m}^{2} \cdot \mathrm{s}^{-1}$ and $2 \%$ respectively, for the superficial aquifer was required to fit both drawdowns and derivatives (plot in (Figure 8a, results in (Table 4).

For modeling the hydraulic behavior of the hydrological system at global scale after the first 8 hours of pumping, Moench's model (Moench, 1984) proved to be the simplest and most efficient model to reproduce the data ((Figure $8 \mathrm{~b})$. The estimated transmissivity of the fractured system is $T 1=$ 
$35710^{-4} \mathrm{~m}^{2} \cdot \mathrm{s}^{-1}$, embedded within a reservoir (matrix) with a lower permeability of $\mathrm{Kb}=2 \cdot 10^{-8} \mathrm{~m} \cdot \mathrm{s}^{-1}$

358 and a relatively high specific storage of $S b=10^{-3} \mathrm{~m}^{-1}$. A high value of fracture skin is still necessary

359 to reproduce the transitory flow regime observed during transitory pumping times (Figure 6). The

360 transmissivity deduced for long times pumping tends to the transmissivity of the global permeable

361 system (Butler and Liu, 1991).

362

363

364

Note that the estimation of storativity in adjacent blocks based on Moench's model is relatively large. However, storativity is in general difficult to estimate in heterogeneous crystalline rocks (Burbey, 2003; Le Borgne et al., 2006a; Meier et al., 1998; Neuman, 1979). This higher value may also reflect the fact that only two main compartments (fracture and matrix) were used in the model, whereas several capacitive domains, including a superficial one in the weathered rocks, may actually be involved in the response to pumping.

\section{(Figure 8)}

\subsubsection{GEOCHEMISTRY AND GROUNDWATER DATING}

Chemical analyses of major ions revealed $\mathrm{Ca}-\mathrm{Mg}-\mathrm{CO}_{3}$ in water from the fault zone and $\mathrm{Ca}-\mathrm{Mg}-\mathrm{CO}_{3}$ $\mathrm{SO}_{4}-\mathrm{Cl}$, characteristic of anthropogenic activities, in water from the shallower weathered domain. $\mathrm{A}$ clear evolution of groundwater chemistry was observed during pumping, due to the mixing of water of different origins. In particular, mixing with the upper weathered reservoir was clearly apparent during the first ten days of pumping. The geochemical response after a longer period was dependent both on shallower and "matrix" contributions and modified by reactivity processes. Description of geochemical evolution will require a much more detailed analysis and will be published in another article (Roques et al., "In Preparation"). Our main focus here is to highlight changes in the apparent age of groundwater, using conservative anthropogenic tracers such as CFCs to highlight the mixing processes. 
380

381

382

383

384

385

386

387

388

389

390

391

392

The evolution of groundwater apparent age was deduced from the CFC- 12 and CFC-113 concentrations in samples taken at the pumping wellhead (

(Figure 9). An asymptotic increase in CFCs concentrations was observed, implying a decrease in apparent age, given the assumption of a piston flow model. Under ambient conditions, the CFCs concentrations in the F3 well were negligible, close to the measurement uncertainty, and characteristic of an apparent age exceeding 55 years. After 60 days of pumping, the mean apparent age of water sampled at the outflow was about 40 years. This clearly confirms the influence of the recent water solicited during pumping. Since old water was found in most of the boreholes, this recent water must come from the upper weathered aquifer $(<10 \mathrm{~m})$. The result also confirms the relatively fast transfer time between compartments.

\section{(Figure 9)}

The contribution of the weathered aquifer may easily be estimated by considering a simple binary mixing assumption. We first assumed that mixing occurred between i) water of high apparent age i.e., 55 years ( $\mathrm{CFC} 12$ concentrations of 0 to $50 \mathrm{pptv}$ ) the representative signature of deep fault water, and ii) water from the upper weathered compartment with a mean apparent age of 20 years (CFC12 concentrations of 550 pptv measured in the superficial boreholes before pumping). Based on these assumptions, the estimated contribution of the upper weathered aquifer was around $15-20 \%$ at the end of pumping (last 30 days, CFC concentration $=105$ pptv).

These observations clearly demonstrate that the superficial compartment contributes to the global mixing process when the deep fault zone aquifer is pumped. It is difficult to clearly define the contribution of each compartment without a detailed analysis of the mixing process (Roques et al., in preparation), which is beyond the scope of the present work. However, both the geochemistry evolution and groundwater dating suggest that after one month of pumping about $20 \%$ of the pumped water comes from the upper part of the aquifer system. 
404

405

406

407

408

409

410

411

412

413

414

415

416

417

418

419

420

421

422

423

424

425

426

427

428

429

\subsubsection{TRACER TESTS}

Two tracer tests were performed during pumping. Uranine tracer was injected in the main productive fault zone in two observation wells: MFT80 and FC4 at 55 and 235 meters depth respectively. (Figure 10 displays the evolution of normalized concentrations with time for the two breakthrough curves. In the first tracer test (MFT80 towards F3), the tracer was detected 4 hours after injection while the maximum concentration occurred at about 16 hours. The estimated travel distance between the injection point in MFT80 and the main inflow zone in F3 was around 53 meters, implying an average flow velocity of about $3.3 \mathrm{~m} / \mathrm{h}$. In the second test (FC4 to F3), the tracer appeared 20 hours after injection and the peak concentration was apparent after about 220h. A slight double peak was observed, certainly due to different flow paths between the two wells. Taking into account a travel distance of about $135 \mathrm{~m}$, the estimated average flow velocity in the deep structure was $0.6 \mathrm{~m} / \mathrm{h}$, i.e. 5.5 times slower than in the upper part of the fault zone. This implies either that the Darcy velocities were much lower in the deeper compartment or that porosity in the deeper compartment was much higher.

The Becker and Charbeneau (2000) solution for converging radial flow was used to compute the present breackthrough curves (Figure 10). The use of this model is justified for highly dispersive system like this one (Peclet number are around 5 , where $\mathrm{Pe}=\mathrm{R} / \alpha$, with $\mathrm{R}$ is the travel distance and $\alpha$ the dispersivity). The modeling objectives are to derive first order transport parameters and to estimate roughly flow partitioning within the permeable fault zone ((Figure 10). The modeling was achieved by setting the injected mass to the restitution rate (around $85 \%$ for MFT80 and $45 \%$ for FC4). It was not possible to use the same set of parameters to fit the two breakthrough curves ((Figure 10). Firstly, dispersivity was apparently two times higher during the deeper tracer test (FC4). This increase in dispersivity can be explained by a scaling effect that is classically observed in large scale tracer tests (Gelhar, 1992) and due to the integration of heterogeneities along pathways. Secondly, fitting both curves would require either constant flow rates or constant parameters for the fault zone (thickness and porosity). Assuming an average fault thickness of 6 meters and a constant 
430 porosity of around 1 to $2 \%$ we were able to obtain a relatively good match for both breackthrough 431 curves ((Figure 10). Porosity values obtained in this case appears relatively high for crystalline rocks,

432 but still reasonable, considering FC4 cores samples (Figure 2), which show that the productive zones 433 are highly fractured and open. The difference in restitution time between the two tracer tests could 434 be honored in this case only by using different effective flowrates for the two tracer tests. This 435 interpretation would imply that the flow-rate from the upper of the aquifer system represented about $2 / 3$ of the total pumping rate while the flow rate from the deeper part was limited to the other $1 / 3$.

Note that the difference in restitution time could be similarly modeled by assuming a permeability decrease with depth or a porosity increase with depth. However, an increase of porosity with depth would be difficult to explain, and permeability, as deduced from previous single borehole tests, appears to remain relatively constant with fault deepening ((Table 2). Such differences may be also partly the results of fault zone heterogeneities. Nevertheless, in both cases tracer injection were done in fractured zone of similar local permeability values. It therefore seems more reasonable to model both tracer tests by assuming flow partitioning through depth. 
4475 DISCUSSION: CONCEPTUAL MODEL

448 The results obtained in the previous sections were synthesized to derive a global conceptual model

449 of the Saint-Brice en Coglès aquifer system. Our aim was to describe the hydraulic functioning of this

450 steep fault zone under ambient and pumping conditions, and to estimate the groundwater resources

451 actually available.

\subsection{SUB-VERTICAL STRUCTURE PROPERTIES AND IMPACT ON GROUNDWATER FLOW}

453

454

455

456

457

458

459

460

461

462

463

464

465

466

467

468

469
The main permeable structure has developed along an extensive normal fault zone. Boreholes at different depth (MFT80, F3 and FC4) were used to investigate the fault zone properties. The fault permeability appears relatively constant with depth and constitutes a sub-vertical strip fractured zone embedded in low-permeability domains and overlain by a weathered horizontal unconfined domain which does not exceed 10 meters depth ( $T_{i}$ piezometers).

Various complementary approaches were used to characterize the discharge of deep groundwater through the sub-vertical permeable fault zone. Geochemistry and groundwater dating indicated the presence of an old water signature in the fractured domain from 250 to $20 \mathrm{~m}$. As the hydraulic heads in the deeper part are higher, the deep water finds a preferential flow path along the permeable fault zone and is discharged towards the subsurface aquifer domains in the watershed outlet ((Figure 11a). Fluxes from the deeper part of the aquifer system can be quantified from the fault zone permeability deduced from hydraulic tests and the mean hydraulic gradient between the deep and subsurface domain. Assuming that the flowrate is constant along the length of the fault (about $1000 \mathrm{~m}$ deduced from the estimated lineament length), the discharge ranges between 170 and $200 \mathrm{~m}^{3} /$ day. Although this amount of natural flux along fault zones is significant, it is generally poorly known, and is not usually considered in the local hydrogeological balance.

(Figure 11) 
A multi-disciplinary approach was adopted to investigate flow behavior and water exchanges between the different aquifer domains which enabled us to derive a conceptual model of the

474 hydraulic behavior of this deep permeable fault zone.

475 The most relevant observation is that the sub-vertical fault is clearly connected with the sub-surface reservoir and the two compartments are therefore highly dependent on each other. Globally, pumping in the deep structure induces downward groundwater flow from the upper aquifer domain ((Figure 11b). Due to the limited storage in the fault zone, water fluxes during pumping are mainly supported by the overlaying reservoir and/or adjacent domains. After two months of water extraction, it is clear that pumping involves contributions from the surrounding compartments, which implies sub-surface and lateral inflows (matrix storage) towards the sub-vertical structure. Tracer test analyses showed that about $2 / 3$ of the water flow originates from the upper part of the aquifer system. This partition of fluxes seems to be governed mainly by hydraulic boundary conditions which limit the deep supply during pumping. As a result, the superficial part of the aquifer seems to constitute a key reservoir supplying the faulted bedrock domain during pumping. The lateral influence of pumping seems to be limited to 300 meters from the fault, as observed in some subsurface boreholes. Thus, in the case of a fault with a large dip (approximately $70^{\circ}$ ) and a high permeability contrast with surrounding compartments, the radial expansion of the drawdown and pressure variation is preferentially transferred along the fault zone. In the present case, pressure variations diffuse mainly along the graben structure, in the lower topographic zone where the wetland has developed ((Figure 11b). This behavior implies that fault zones, when they are permeable, may allow pressure diffusion along the fault plane that can act almost as a boundary condition to drain groundwater from the surrounding reservoirs. Similar behavior has been described through numerical modeling of groundwater flow in fault zones (Leray et al., 2013). 


\section{CONCLUSIONS}

497 In this study, we used a multidisciplinary approach to investigate the hydrogeologic behavior of a

498 sub-vertical permeable fault and quantify its interactions with surrounding reservoirs, under ambient

499 and pumping conditions. This study provides a good example of the functioning of a sub-vertical fault

500 determined from lineament mapping.

501 Our results suggest that sub-vertical fault and sub-surface reservoirs are highly dependent on each 502 other. Under ambient conditions, the fault allows the discharge of regional old water into superficial 503 aquifer domains. The natural discharge rate of the fault zone is estimated to be around 170 to 200

$504 \mathrm{~m}^{3} /$ day. Although relatively low, this value should be taken into account when estimating water 505 fluxes, hydrologic budget and solute transport at the watershed scale. During the early stages of 506 pumping, the hydrological system is strongly dependent on storage from the sub-surface weathered

507 reservoir. Once the upper weathered reservoir has become mainly unsaturated, the system acts as a 508 classic dual porosity medium with a highly transmissive structure embedded in lower permeable 509 compartments. Thus, this high permeability fault zone appears to be an efficient thin permeable 510 domain that permits rapid diffusion of pressure but is strongly dependent on sub-surface and 511 adjacent domains of higher storativity. All field measurements suggest that under pumping 512 conditions, most of the flow comes from superficial domains and from the vicinity of the fault zone, 513 with a recharge area located at the surface mainly along the fault zone. Moreover, such steep fault 514 zones, although of relatively high transmissivity, remain relatively limited in terms of groundwater 515 yield. In this study, the pumping test was carried out for 2 months at a flow-rate of $45 \mathrm{~m}^{3} / \mathrm{h}, \mathrm{but}^{\mathrm{b}}$ the 516 piezometric analysis indicates that this rate was certainly too high to be sustainable. A better 517 estimate of sustainable flowrate would be around 20 to $30 \mathrm{~m}^{3} / \mathrm{h}$. This is a much lower value than 518 some other fault zone aquifers, such as gently dipping fault zones which may provide higher 519 groundwater resources (Le Borgne et al., 2006a; Ruelleu et al., 2010). This difference confirms the 
520 role of the dip of the fault-zone that may greatly increase borehole yield in some circumstances

521 (Leray et al., 2013).

\section{Acknowledgments}

523 Most funding came from the CASPAR project in collaboration with OSUR and BRGM and co-funded

524 by the French Water Agency of Loire-Brittany (AELB), the Regional of Council of French Brittany, the

525 Department of lle-et-Vilaine and the French Ministry for Education and Research. We also wish to

526 thank the European Interreg IV project Climawat, which partly funded some of the experiments. We

527 want to thank Matthew Becker and anonymous reviewer for their very constructive and encouraging

528 comments. We would also like to thank Nicolas Guihéneuf for his help to interpret our tracer test

529 results. We thank all the people who were involved in the project: Odile Hénin, Martine Bouhnik-Le

530 Coz, Patrice Petitjean, Patricia Madec, Hélène Pauwels, Flora Lucassou, Jean-Pierre Jegou, Eric

531 Palvadeau, Antoine Armandine Les-Landes, Joaquin Jimenez-Martinez, Pascal Goderniaux, Thomas

532 Stieglitz, Stéphane Durand, Ghislain Ferre, Olivier Dauteil, Christian Camerlynck, Pierre-Yves Galibert,

533 Fayçal Rejiba, Philippe Bardy, Antoine Rivera... 
Amiotte Suchet, P., Probst, J.-L., Ludwig, W., 2003. Worldwide distribution of continental rock lithology: Implications for the atmospheric/soil CO 2 uptake by continental weathering and alkalinity river transport to the oceans. Global Biogeochem. Cycles 17, $1-13$.

Anderson, E.I., Bakker, M., 2008. Groundwater flow through anisotropic fault zones in multiaquifer systems. Water Resour. Res. 44, 1-11.

Anderson, M.P., 2005. Heat as a ground water tracer. Ground Water 43, 951-68.

Apaydin, A., 2010. Relation of tectonic structure to groundwater flow in the Beypazari region, NW Anatolia, Turkey. Hydrogeol. J. 18, 1343-1356.

Aydin, A., 2000. Fractures, faults, and hydrocarbon entrapment, migration and flow. Mar. Pet. Geol. 17, 797-814.

Ayraud, V., Aquilina, L., Labasque, T., Pauwels, H., Molenat, J., Pierson-Wickmann, A.-C., Durand, V., Bour, O., Tarits, C., Le Corre, P., 2008. Compartmentalization of physical and chemical properties in hard-rock aquifers deduced from chemical and groundwater age analyses. Appl. Geochemistry 23, 2686-2707.

Bahat, D., 1999. Mechanism of exfoliation joint formation in granitic rocks, Yosemite National Park. J. Struct. Geol. 21, 85-96.

Ballèvre, M., Bosse, V., Ducassou, C., Pitra, P., 2009. Palaeozoic history of the Armorican Massif: Models for the tectonic evolution of the suture zones. Comptes Rendus Geosci. 341, 174-201.

Banwart, S., Gustafsson, E., Laaksoharju, M., 1994. Fracture zone in crystalline bedrock: Initial hydrochemical perturbation during tunnel construction at the Äspö Hard Rock Laboratory, southeastern Sweden. Water Resour. Res. 30, 1747-1763.

Becker, M.W., Charbeneau, R., 2000. First-passage-time transfer functions for groundwater tracer tests conducted in radially convergent flow. J. Contam. Hydrol. 40, 299-310.

Bense, V.F., Person, M. a., 2006. Faults as conduit-barrier systems to fluid flow in siliciclastic sedimentary aquifers. Water Resour. Res. 42, 1-18.

Bense, V.F., Person, M. a., Chaudhary, K., You, Y., Cremer, N., Simon, S., 2008. Thermal anomalies indicate preferential flow along faults in unconsolidated sedimentary aquifers. Geophys. Res. Lett. 35, 1-6.

Bense, V.F., Van den Berg, E.H., Van Balen, R.T., 2003. Deformation mechanisms and hydraulic properties of fault zones in unconsolidated sediments; the Roer Valley Rift System, The Netherlands. Hydrogeol. J. 11, 319-332.

Blatt, H., Jones, R., 1975. Proportions of exposed igneous, metamorphic, and sedimentary rocks. Geol. Soc. Am. Bull. 86, 1085-1088. 
571

605 606

Bourdet, D., Ayoub, J., 1989. Use of pressure derivative in well test interpretation. SPE Form. Eval. 4, 293-302.

Bourdet, D., Whittle, T., Douglas, A., Pirard, Y., 1983. A new set of type curves simplifies well test analysis. World Oil 196, 95-106.

Boutt, D.F., Diggins, P., Mabee, S., 2010. A field study (Massachusetts, USA) of the factors controlling the depth of groundwater flow systems in crystalline fractured-rock terrain. Hydrogeol. J. 18, 1839-1854.

Brun, J.-P., Guennoc, P., Truffert, C., Vairon, J., 2001. Cadomian tectonics in northern Brittany: a contribution of 3-D crustal-scale modelling. Tectonophysics 331, 229-246.

$\mathrm{Bu}, \mathrm{X}$. , Warner, M.J., 1995. Solubility of chlorofluorocarbon 113 in water and seawater. Deep Sea Res. Part I Oceanogr. Res. Pap. 42, 1151-1161.

Burbey, T.., 2003. Use of time-subsidence data during pumping to characterize specific storage and hydraulic conductivity of semi-confining units. J. Hydrol. 281, 3-22.

Busenberg, E., Plummer, L.N., 1992. Use of chlorofluorocarbons (CCI3F and CCI F2) as hydrologic tracers and age-dating tools: The alluvium and terrace system of central Oklahoma. Water Resour. Res. 28, 2257-2283.

Butler, J.J., Liu, W.Z., 1991. Pumping tests in non-uniform aquifers: the linear strip case. J. Hydrol. 128, 69-99.

Caine, J., Evans, J., Forster, C., 1996. Fault zone architecture and permeability structure. Geology 24, 1025-1028.

Caine, J.S., Tomusiak, S.R.A., 2003. Brittle structures and their role in controlling porosity and permeability in a complex Precambrian crystalline-rock aquifer system in the Colorado Rocky Mountain Front Range. GSA Bull. 115, 1410-1424.

Carn-Dheilly, A., Thomas, E., 2008. RAPSODI - Recherche d'aquifères profonds dans le socle du département de l'Ille et Vilaine. Rapport Final - BRGM/RP-56749-FR.

Carucci, V., Petitta, M., Aravena, R., 2012. Interaction between shallow and deep aquifers in the Tivoli Plain (Central Italy) enhanced by groundwater extraction: A multi-isotope approach and geochemical modeling. Appl. Geochemistry 27, 266-280.

Chantraine, J., Egal, E., Thiéblemont, D., Le Goff, E., Guerrot, C., Ballèvre, M., Guennoc, P., 2001. The Cadomian active margin (North Armorican Massif, France): a segment of the North Atlantic Panafrican belt. Tectonophysics 331, 1-18.

Chatelier, M., Ruelleu, S., Bour, O., Porel, G., Delay, F., 2011. Combined fluid temperature and flow logging for the characterization of hydraulic structure in a fractured karst aquifer. J. Hydrol. 400, 377-386.

Chilton, P.J., Foster, S.D.S., 1995. Hydrogeological characterization and water-supply potential of basement aquifers in tropical Africa. Hydrogeol. J. 3, 36-49. 
607

608

609

610

611

612

613

614

615

616

617

618

619

620

621

622

623

624

625

626

627

628

629

630

631

632

633

634

635

636

637

638

639

640

641

642

643

644

Cogné, J., Wright, A.E., 1980. L'orogène Cadomien - Geology of Europe from Precambrian to the post-Hercynian sedimentary basins. 26th Int. Geol. Congr. - BRGM Mem 108, 29-55.

Cook, P., Love, a, Robinson, N., Simmons, C., 2005. Groundwater ages in fractured rock aquifers. J. Hydrol. 308, 284-301.

Cook, P., Solomon, D., 1997. Recent advances in dating young groundwater: chlorofluorocarbons, 3H/3He and 85Kr. J. Hydrol. 191, 245-265.

Dadet, P., Beurrier, M., Lautridou, J.-P., 1984. Notice explicative de la feuille Saint-HilaireDu-Harcouët à 1/50 000. BRGM, Orléans.

Dewandel, B., Lachassagne, P., Wyns, R., Maréchal, J.C., Krishnamurthy, N.S., 2006. A generalized 3-D geological and hydrogeological conceptual model of granite aquifers controlled by single or multiphase weathering. J. Hydrol. 330, 260-284.

Escobar, F.H., Hernández, D.P., 2010. Pressure and pressure derivative analysis for long naturally fractured reservoirs using the TDS technique. DYNA 77, 102-114.

Evans, J.P., Forster, C.B., Goddard, J. V., 1997. Permeability of fault-related rocks, and implications for hydraulic structure of fault zones. J. Struct. Geol. 19, 1393-1404.

Fernandes, A., Rudolph, D., 2001. The influence of Cenozoic tectonics on the groundwaterproduction capacity of fractured zones: a case study in Sao Paulo, Brazil. Hydrogeol. J. 9, 151-167.

Folch, A., Mas-Pla, J., 2008. Hydrogeological interactions between fault zones and alluvial aquifers in regional flow systems. Hydrol. Process. 22, 3476-3487.

Ganerod, G.V., Braathen, A., Willemoes-Wissing, B., 2008. Predictive permeability model of extensional faults in crystalline and metamorphic rocks; verification by pre-grouting in two sub-sea tunnels, Norway. J. Struct. Geol. 30, 993-1004.

Gannon, J.P., Burbey, T.J., Bodnar, R.J., Aylor, J., 2011. Geophysical and geochemical characterization of the groundwater system and the role of Chatham Fault in groundwater movement at the Coles Hill uranium deposit, Virginia, USA. Hydrogeol. J. $20,45-60$.

Gelhar, L., 1992. A critical review of data on field-scale dispersion in aquifers. Water Resour. Res. 28, 1955-1974.

Gleeson, T., Novakowski, K., 2009. Identifying watershed-scale barriers to groundwater flow:

Goddard, J. V., Evans, J.P., 1995. Chemical changes and fluid-rock interaction in faults of crystalline thrust sheets, northwestern Wyoming, U.S.A. J. Struct. Geol. 17, 533-547.

Grellet, B., Combes, P., Granier, T., Philip, H., 1993. Sismotectonique de la France métropolitaine dans son cadre géologique et géophysique. Mem. N.S. SGF 164 1-2.

Gringarten, E., 1996. 3-D geometric description of fractured reservoirs. Math. Geol. 28, 881893. 
Harte, P., Robinson, G., Ayotte, J., Flanagan, S., 2008. Framework for Evaluating Water Quality of the New England Crystalline Rock Aquifers. U.S. Geol. Surv. Open-File Rep. 2008-1282 47.

Henriksen, H., Braathen, A., 2005. Effects of fracture lineaments and in-situ rock stresses on groundwater flow in hard rocks: a case study from Sunnfjord, western Norway. Hydrogeol. J. 14, 444-461.

Holland, M., Witthüser, K.T., 2011. Evaluation of geologic and geomorphologic influences on borehole productivity in crystalline bedrock aquifers of Limpopo Province, South Africa. Hydrogeol. J. 19, 1065-1083.

Hunt, B., Scott, D., 2007. Flow to a Well in a Two-Aquifer System. J. Hydrol. Eng. 12, 146155.

Jaunat, J., Huneau, F., Dupuy, A., Celle-Jeanton, H., Vergnaud-Ayraud, V., Aquilina, L., Labasque, T., Le Coustumer, P., 2012. Hydrochemical data and groundwater dating to infer differential flowpaths through weathered profiles of a fractured aquifer. Appl. Geochemistry 27, 2053-2067.

Labasque, T., 2006. Analyse des CFC dans les eaux souterraines. Géosciences Rennes, Cahiers techniques de Géosciences Rennes, Rennes.

Le Borgne, T., Bour, O., Paillet, F., Caudal, J., 2006a. Assessment of preferential flow path connectivity and hydraulic properties at single-borehole and cross-borehole scales in a fractured aquifer. J. Hydrol. 328, 347-359.

Le Borgne, T., Paillet, F., Bour, O., Caudal, J.-P., 2006b. Cross-borehole flowmeter tests for transient heads in heterogeneous aquifers. Ground Water 44, 444-52.

Leray, S., de Dreuzy, J.-R., Bour, O., Bresciani, E., 2013. Numerical modeling of the productivity of vertical to shallowly dipping fractured zones in crystalline rocks. J. Hydrol. $481,64-75$.

Maréchal, J., Wyns, R., 2004. Vertical anisotropy of hydraulic conductivity in the fissured layer of hard-rock aquifers due to the geological structure of weathering profiles. J. Geol. Soc. India 5, 545-550.

Meier, P.M., Carrera, J., Sánchez-Vila, X., 1998. An evaluation of Jacob's Method for the interpretation of pumping tests in heterogeneous formations. Water Resour. Res. 34, $1011-1025$.

Melchiorre, E.B., Criss, R.E., Davisson, M.L., 1999. Relationship between seismicity and subsurface fluids, central Coast Ranges, California. J. Geophys. Res. 104, 921-939.

Moench, F., 1984. Double-Porosity Models for a Fissured Groundwater Reservoir With Fracture Skin. Water Ressources Res. 20, 831-846.

Neuman, S.P., 1979. Perspective on "Delayed yield". Water Resour. Res. 15, 899-908.

Paillet, F.L., 1998. Flow modeling and permeability estimation using borehole flow logs in heterogeneous fractured formations. Water Resour. Res. 34, 997-1010. 
683

Rafini, S., Larocque, M., 2009. Insights from numerical modeling on the hydrodynamics of non-radial flow in faulted media. Adv. Water Resour. 32, 1170-1179.

Renard, P., Glenz, D., Mejias, M., 2008. Understanding diagnostic plots for well-test interpretation. Hydrogeol. J. 17, 589-600.

Richard, B., Moore, B., Schwarz, G.E., Clark, S.F., Walsh, G.J., Degnan, J.R., 2002. Factors Related to Well Yield in the Fractured-Bedrock Aquifer of New Hampshire. U.S. Geol. Surv. Prof. Pap. 1660, 1-51.

Ruelleu, S., Moreau, F., Bour, O., Gapais, D., Martelet, G., 2010. Impact of gently dipping discontinuities on basement aquifer recharge: An example from Ploemeur (Brittany, France). J. Appl. Geophys. 70, 161-168.

Sander, P., 2006. Lineaments in groundwater exploration: a review of applications and limitations. Hydrogeol. J. 15, 71-74.

Schnegg, P., Costa, R., 2007. Tracer tests made easier with field fluorometers. Bull. d'Hydrogéologie 20, 20-21.

Schnegg, P., Flynn, R., 2002. Online field fluorometers for hydrogeological tracer tests. Isot. und Tracer der Wasserforschung, Tech. Univ. Bergakademie Freiberg, Wissenschaftliche Mitteilungen, Inst. für Geol. 19, 29-36.

Singhal, B., Gupta, R., 2010. Applied Hydrogeology of Fractured Rocks: Second Edition. Springer.

Sophocleous, M., 2002. Interactions between groundwater and surface water: the state of the science. Hydrogeol. J. 10, 52-67.

Spane, F., Wurstner, S., 1993. DERIV: A computer program for calculating pressure derivatives for use in hydraulic test analysis. Ground Water 31, 814-822.

Stober, I., Bucher, K., 1999. Deep groundwater in the crystalline basement of the Black Forest region. Appl. Geochemistry 14, 237-254.

Taylor, R., Howard, K., 2002. A tectono-geomorphic model of the hydrogeology of deeply weathered crystalline rock: Evidence from Uganda. Hydrogeol. J. 8, 279-294.

Taylor, R.G., Howard, K.W.F., 1999. Lithological evidence for the evolution of weathered mantles in Uganda by tectonically controlled cycles of deep weathering and stripping. CATENA 35, 65-94.

Tiab, D., 2005. Analysis of pressure derivative data of hydraulically fractured wells by the Tiab's Direct Synthesis technique. J. Pet. Sci. Eng. 49, 1-21.

Van Vliet-Lanoë, B., Bonnet, S., Hallegouët, M., Laurent, M., 1997. Neotectonic and seismic activity in the Armorican and Cornubian Massifs: Regional stress field with glacioisostatic influence? J. Geodyn. 24, 219-239.

Walker, S.J., Weiss, R.F., Salameh, P.K., 2000. Reconstructed histories of the annual mean atmospheric mole fractions for the halocarbons CFC-11 CFC-12, CFC-113, and carbon tetrachloride. J. Geophys. Res. 105, 14285. 
721

722

723

724

725

726

727

728
Warner, M.J., Weiss, R.F., 1985. Solubilities of chlorofluorocarbons 11 and 12 in water and seawater. Deep Sea Res. Part A. Oceanogr. Res. Pap. 32, 1485-1497.

Weiss, R.F., Price, B.A., 1980. Nitrous oxide solubility in water and seawater. Mar. Chem. 8, 347-359.

Wyns, R., Baltassat, J., Lachassagne, P., Legchenko, A., Vairon, J., 2004. Application of proton magnetic resonance soundings to groundwater reserve mapping in weathered basement rocks (Brittany, France). Bull. la Société Géologique Fr. 175, 21-34. 
1 Figure 1: a) Location map and regional geological map. Star symbol indicates the St Brice Field site, $24^{\circ} 25^{\prime} N 1^{\circ} 22^{\prime} W$, alt. 90m a.s.l. (modified from Chantraine, (Chantraine et al., 2001)). b) Local 3 geological map with main lineaments identified (modified Dadet, (Dadet et al., 1984) \& IGNC).

4

Figure 2: Geological conceptual model of the St Brice field site. a) Conceptual geological structure in a 3D diagram representation, b) local geological map and boreholes location and c) cross-section of the structure perpendicular to the main identified lineament.

Figure 3 : Typical hydraulic head variations measured in the different boreholes at Saint-Brice and precipitations measured during the same period. Rainfall was measured at the nearest meteorological station located 30 kilometers from Saint-Brice.

Figure 4: Flowrate profiles in FC4 borehole under (a) ambient conditions (before pumping), measured with a Heat-Pulse-Flowmeter, and (b) pumping conditions, measured with an Impeller Flowmeter Geovista (C). The blue straight line represents the modeled flow using Paillet solutions (Paillet, 1998).

Figure 5 : Drawdown in the pumping well (F3, blue triangle dots), in observation wells intersecting the fault zone aquifer (FC4, MFT80 and MFT20, gray points) and observation wells located in the shallow aquifer (T1, T2, T3, T5, T6 and T7, black lines)

Figure 6 : Diagnostic plot in Log scales showing drawdown (blue straight line) normalized by flow rate $(s / Q)$, and its derivative (blue point symbol) measured during the long term pumping test in F3. 
Figure 7: Flow and temperature profiles under ambient (grey lines) and pumping conditions (after 9 and 63 days of pumping) in observation well (MFT80).

Figure 8: Drawdown (s) evolution with time and its derivative $\left(s^{\prime}\right)$ during pumping. Observations come from MFT80 observation well. Moench and Boulton (modified Hunt) analytical models were used to fit both drawdown and derivative curves. In a) only the first ten days were fitted while in b) Moench's model was fitted to pumping results obtained at later times.

Figure 9 : Apparent age of water sampled at the outflow and deduced from CFC analysis.

Figure 10: Tracer test data between the shallow aquifer (MFT80, gray point symbol) and the deep fracture (FC4, gray triangle symbol), modeled with the Welty and Gelhar solution (gray straight lines). Parameters used in the model are presented in the table (Welty and Gelhar, 1994).

Figure 11 : Conceptual model of groundwater flow at the St-Brice site under a) ambient conditions and b) pumping conditions

Table 1: Borehole descriptions

Table 2: Transmissivity results obtained by modeling borehole flow profiles using Paillet solutions (Paillet, 1998). 
46

47

J Warner, 1995; M.J. Warner and Weiss, 1985)).

48

49

Table 4: Pumping test results for pumping well F3 and observation wells MFT80, FC4 and MFT20.

50 RMSE is calculated over the analyzed part of the pumping test. 


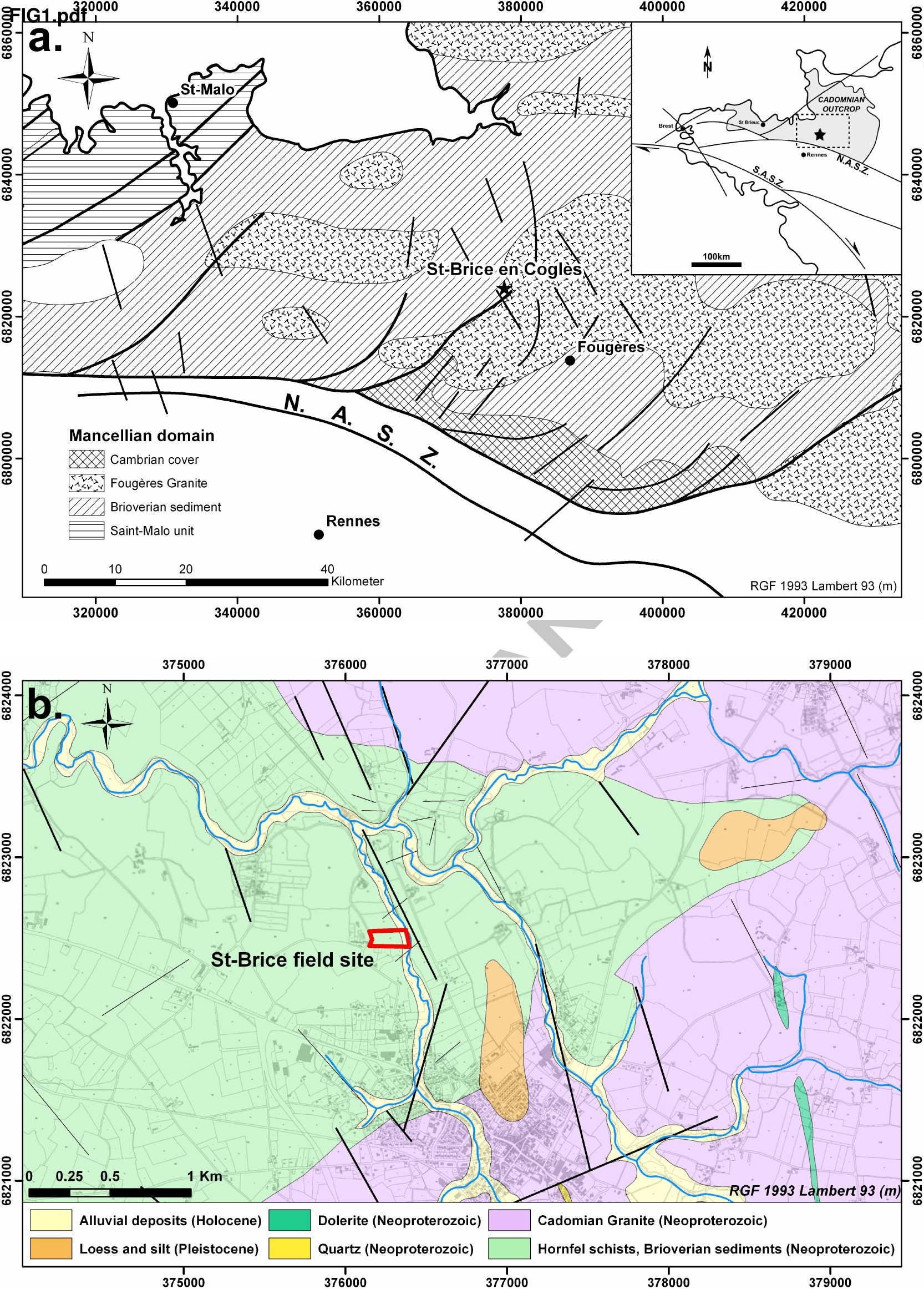


a.
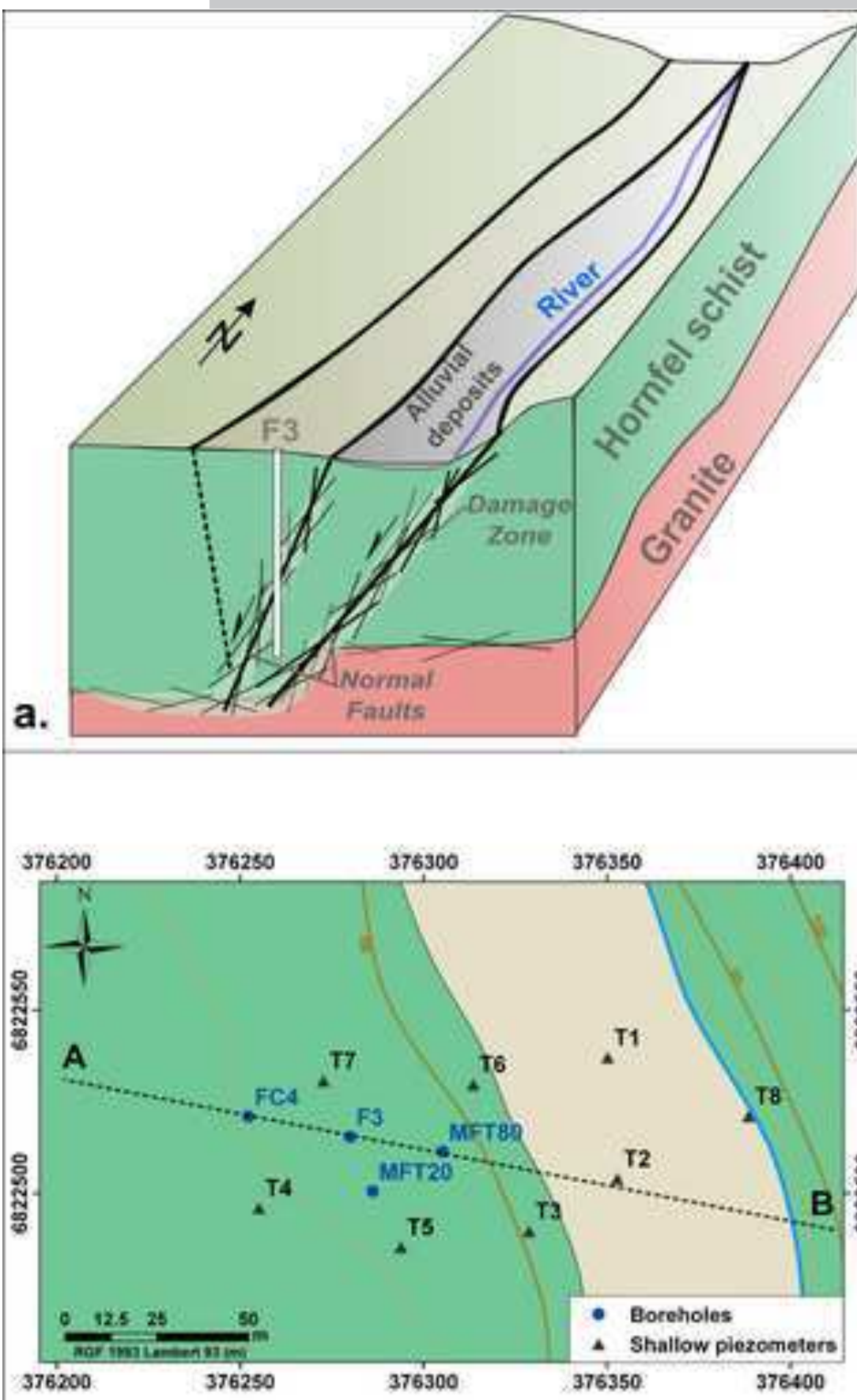

b.

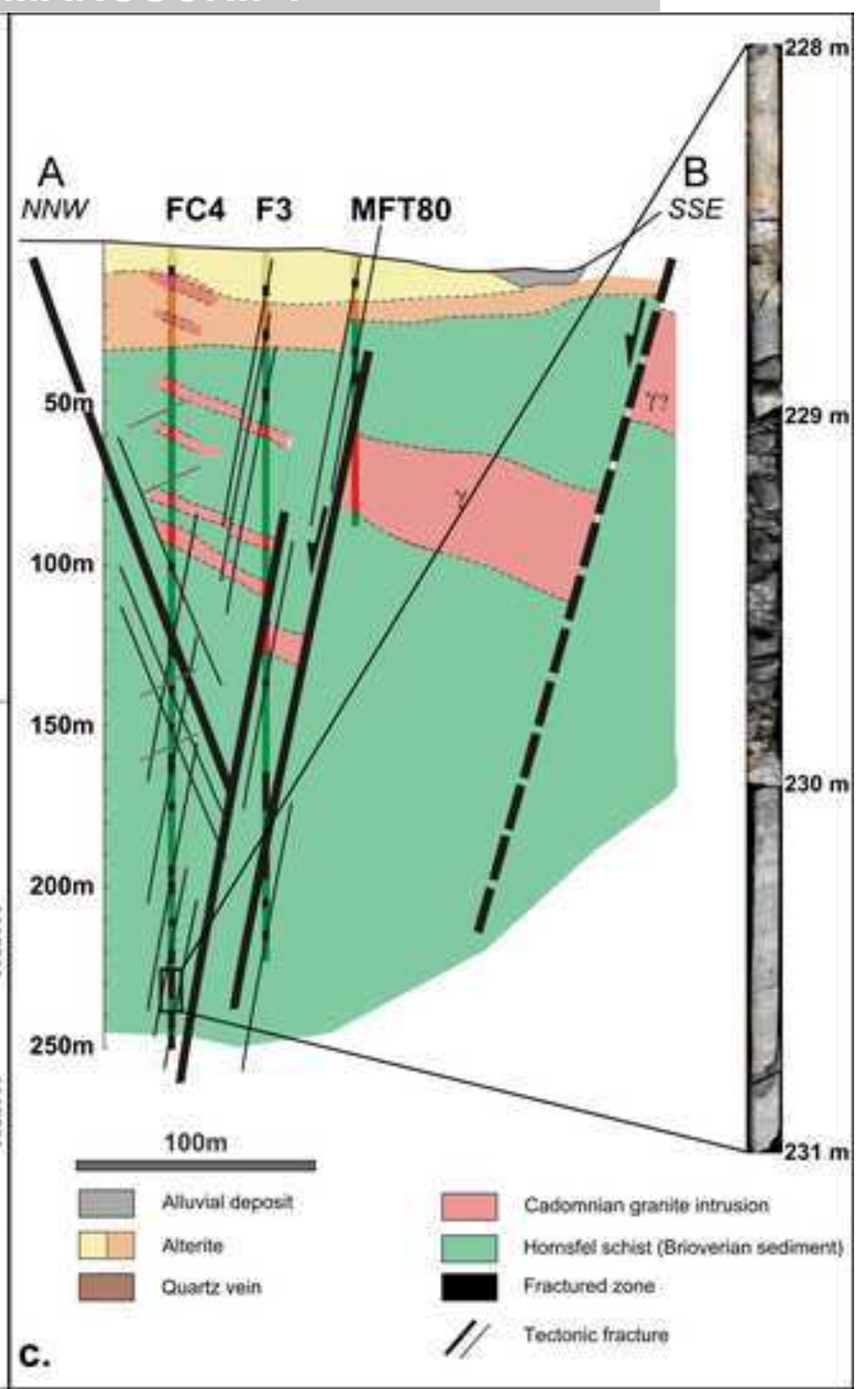

ACCEPTED MANUSCRIPT 


\section{ACCEPTED MANUSCRIPT}
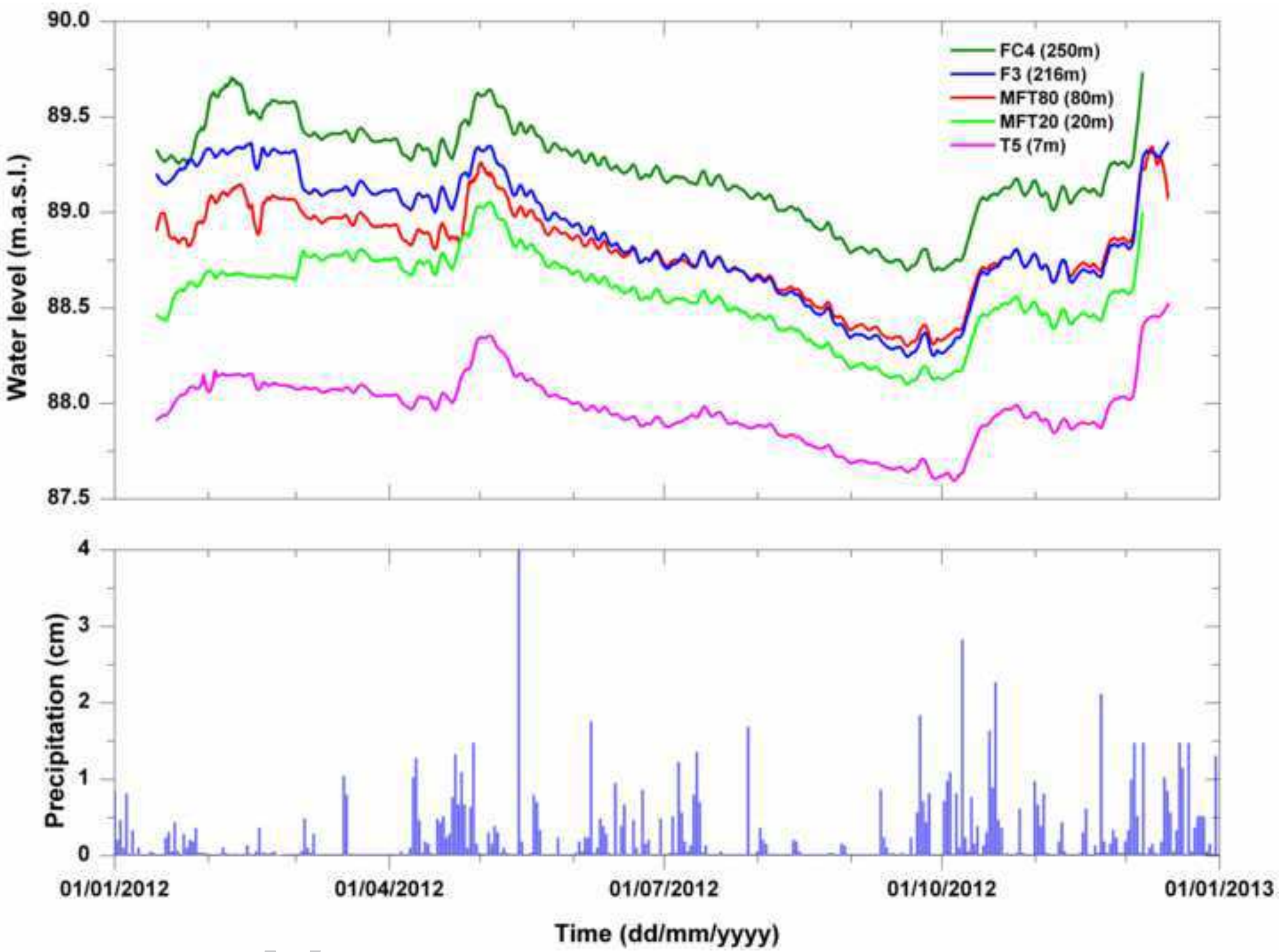


\section{ACCEPTED MANUSCRIPT}

\section{FC4}
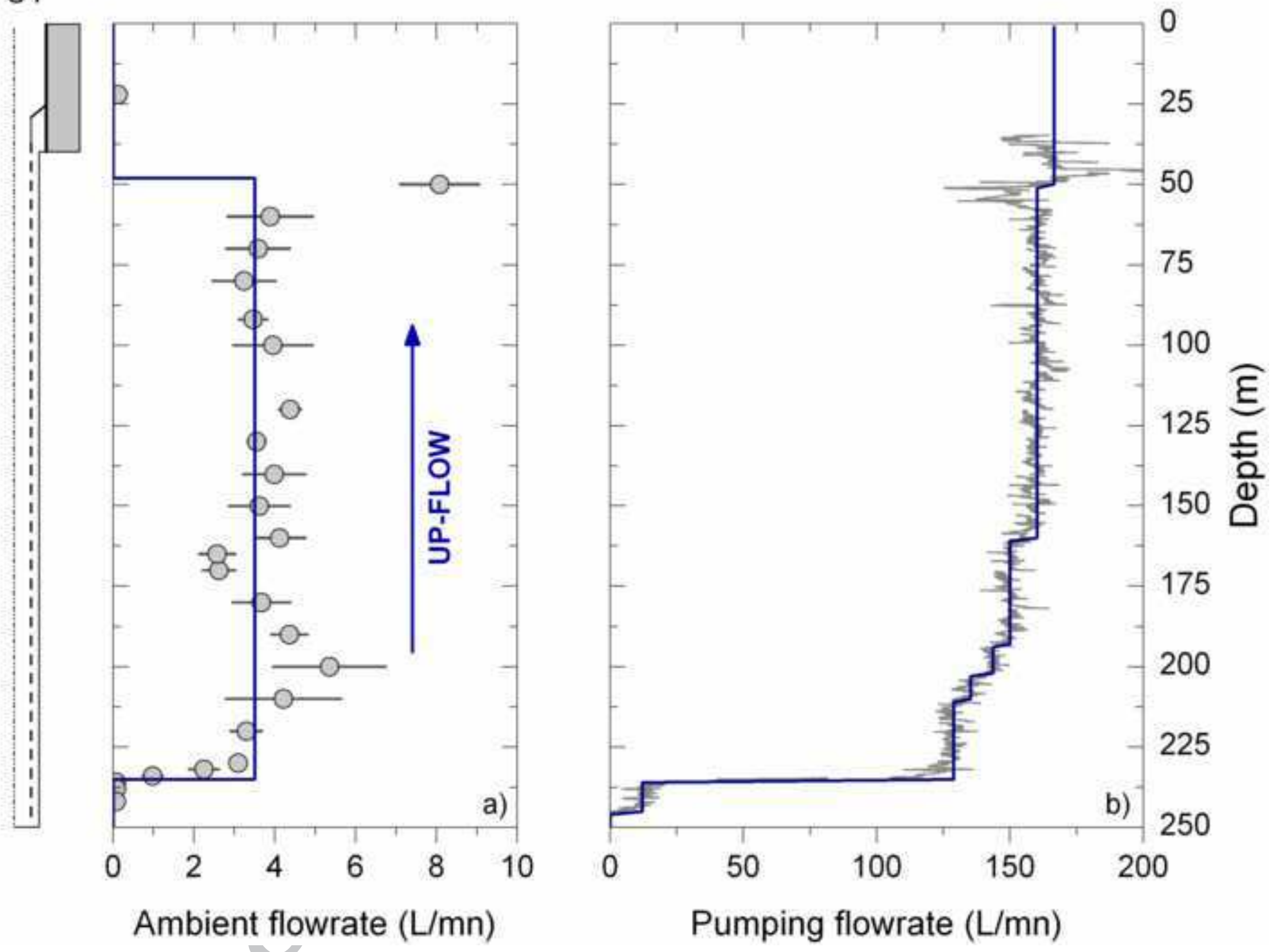
ACCEPTED MANUSCRIPT

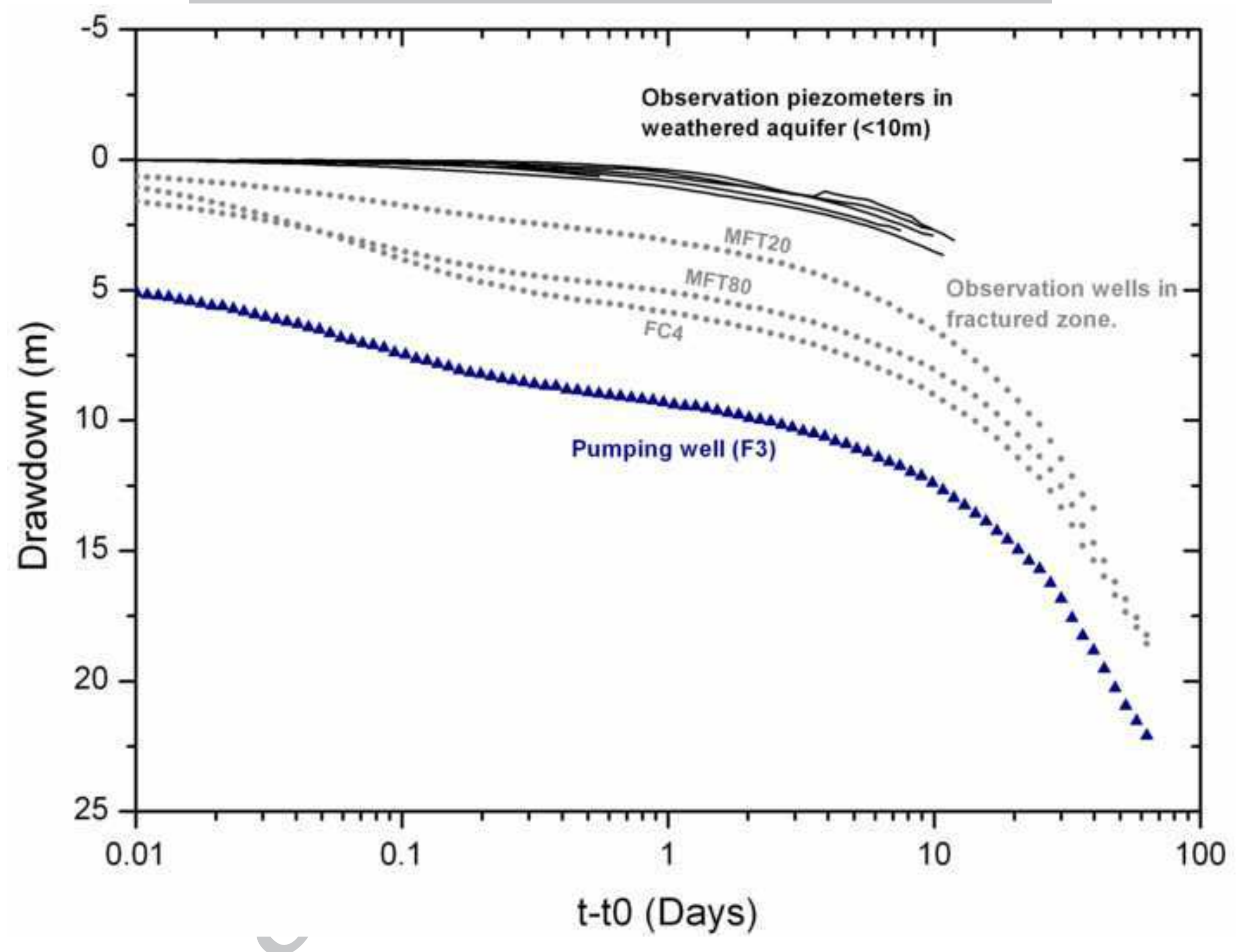


ACCEPTED MANUSCRIPT

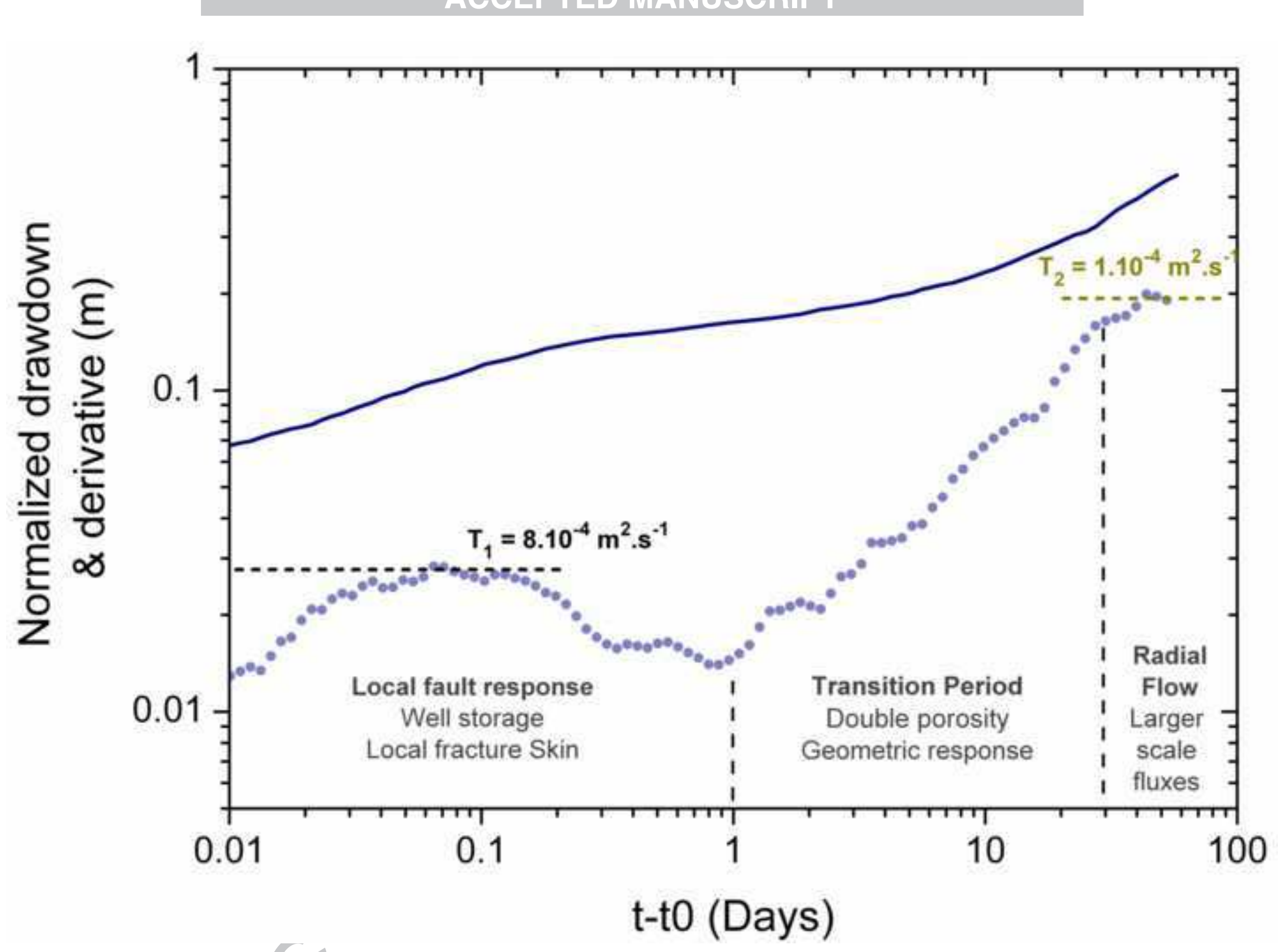



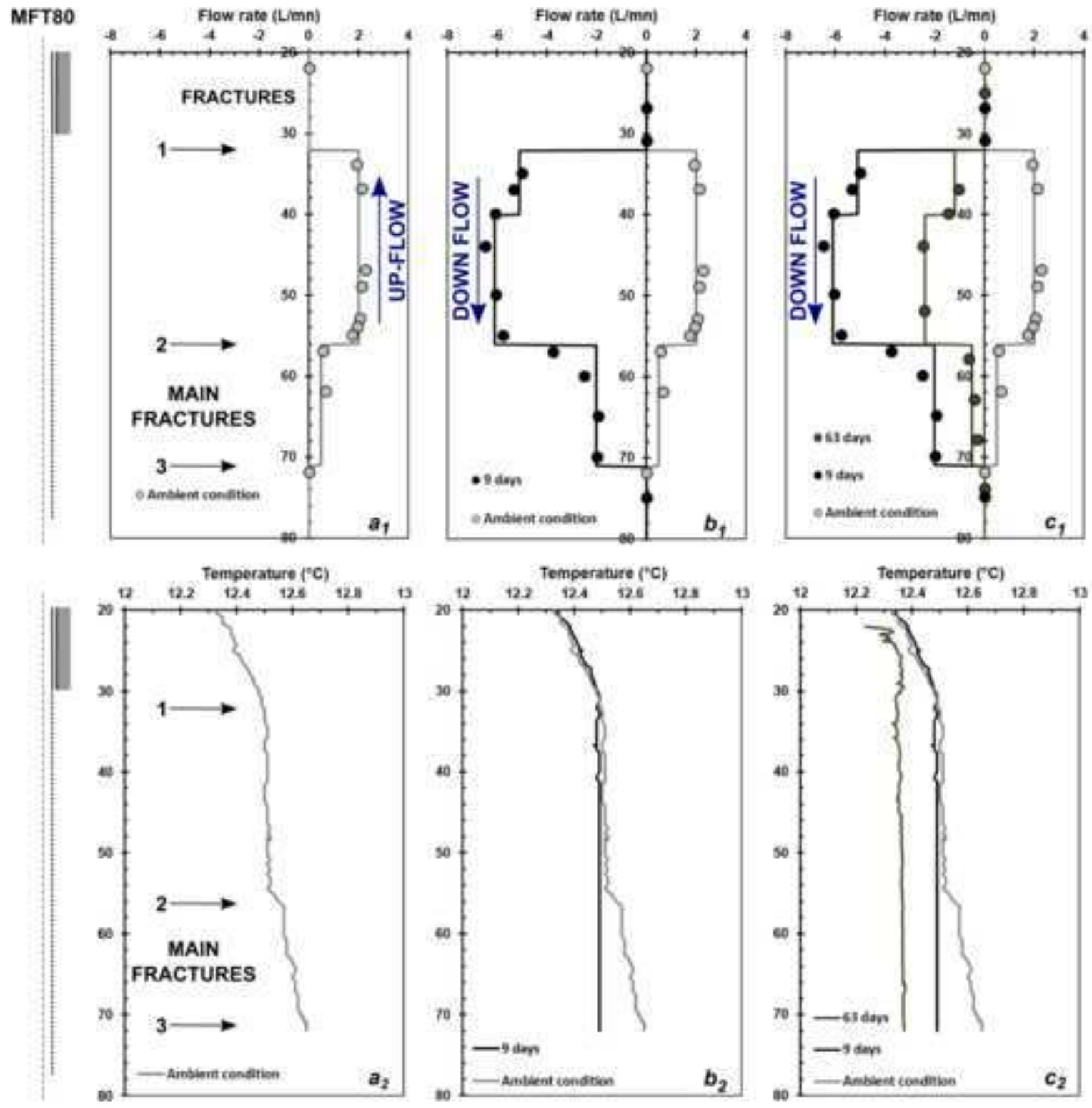


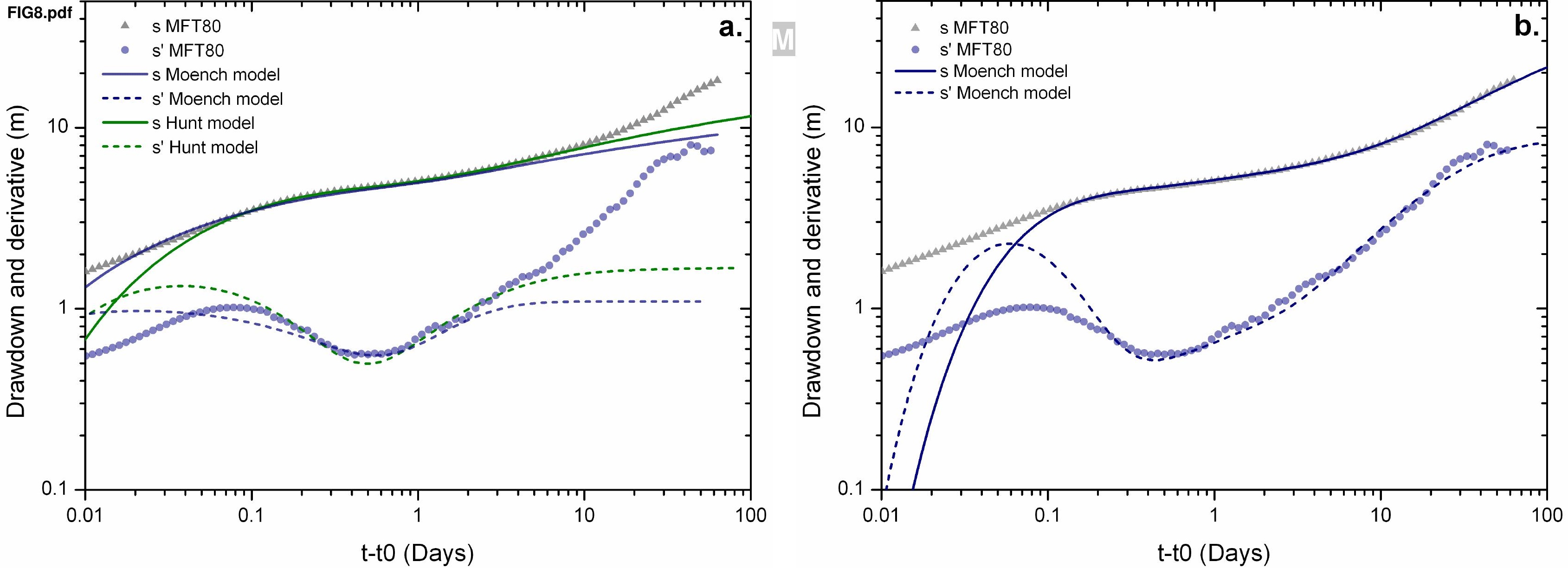


ACCEPTED MANUSCRIPT

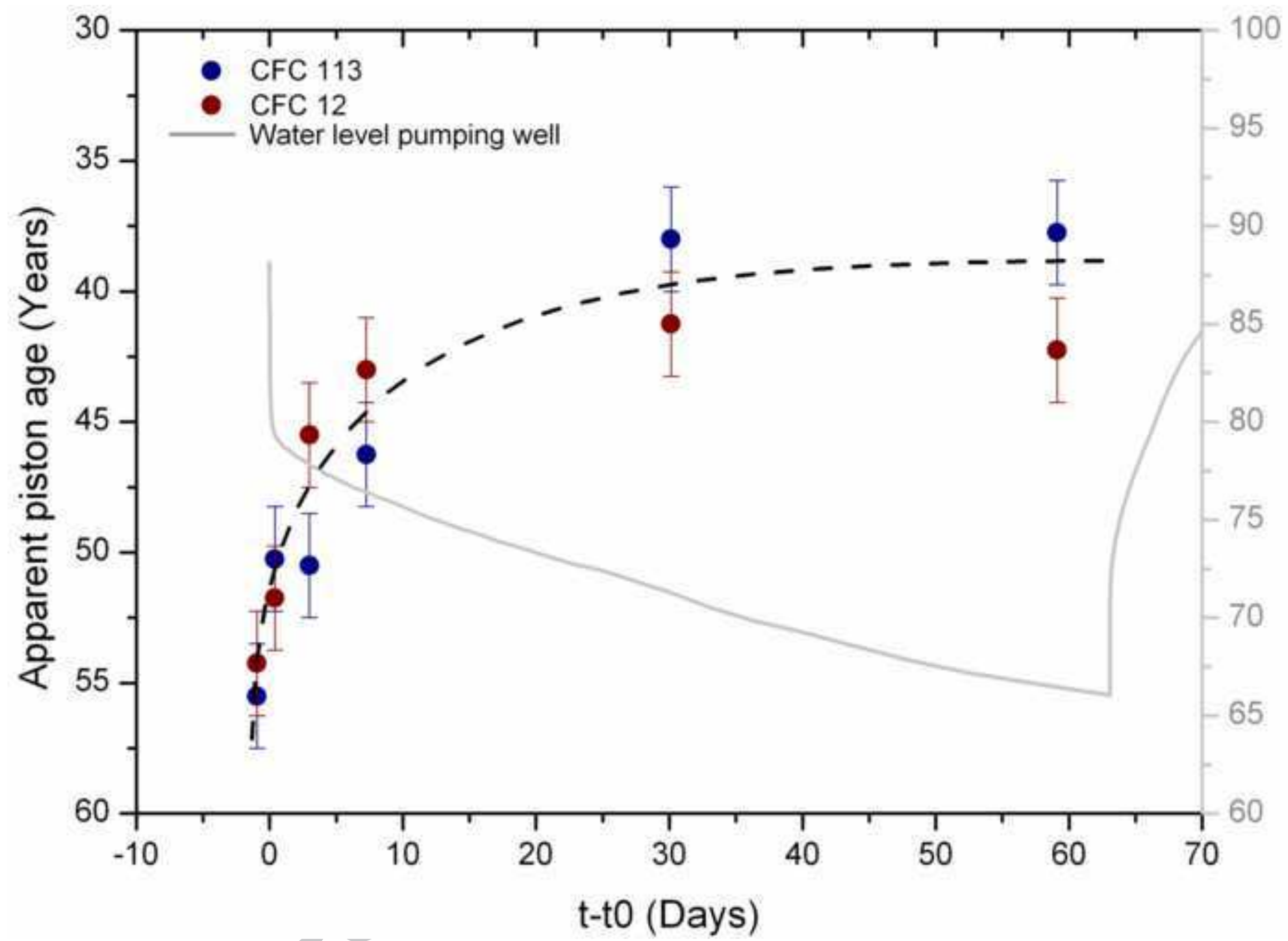

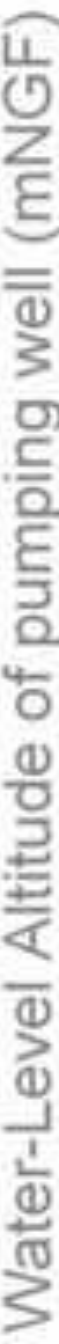


ACCEPTED MANUSCRIPT

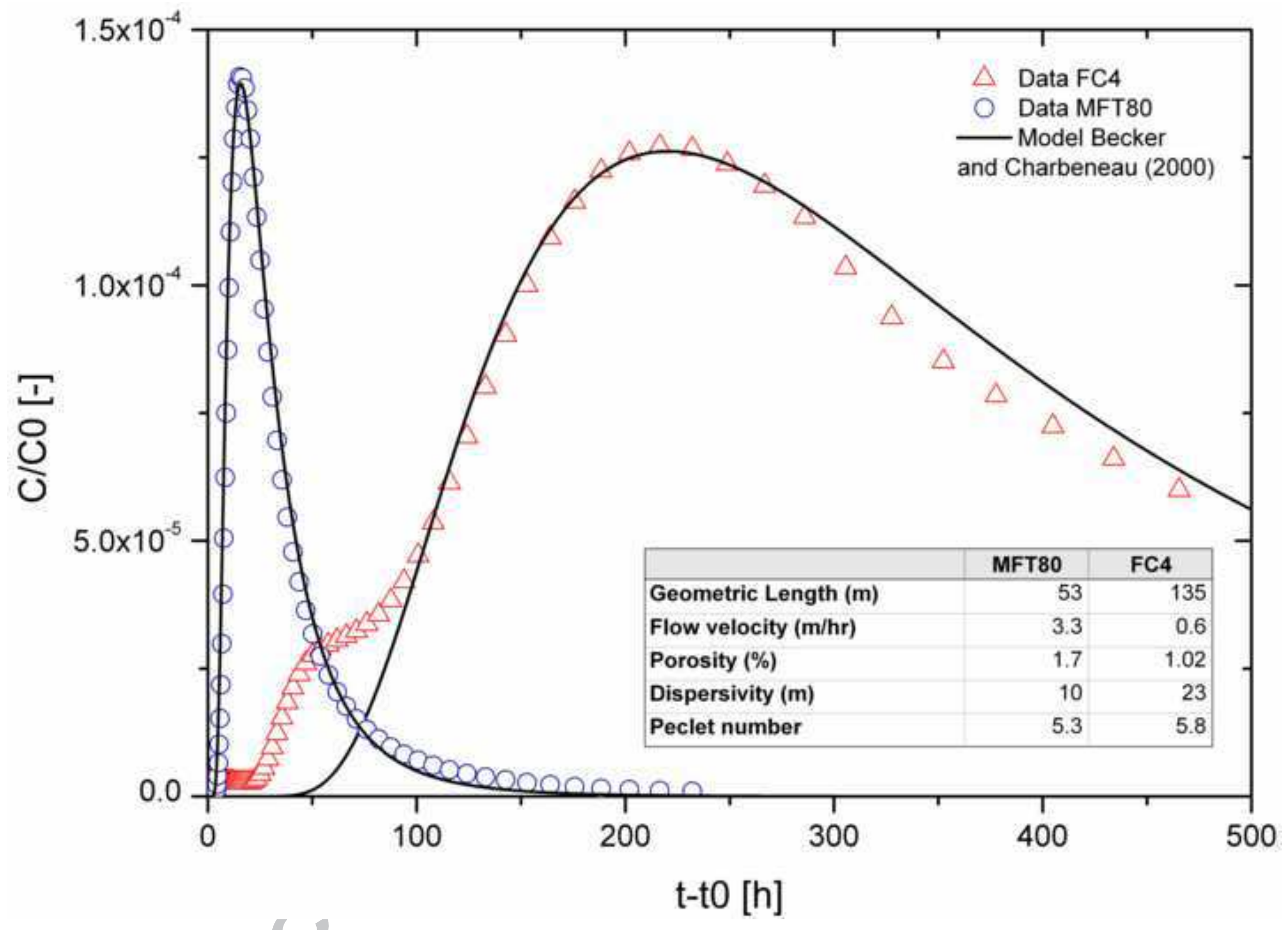



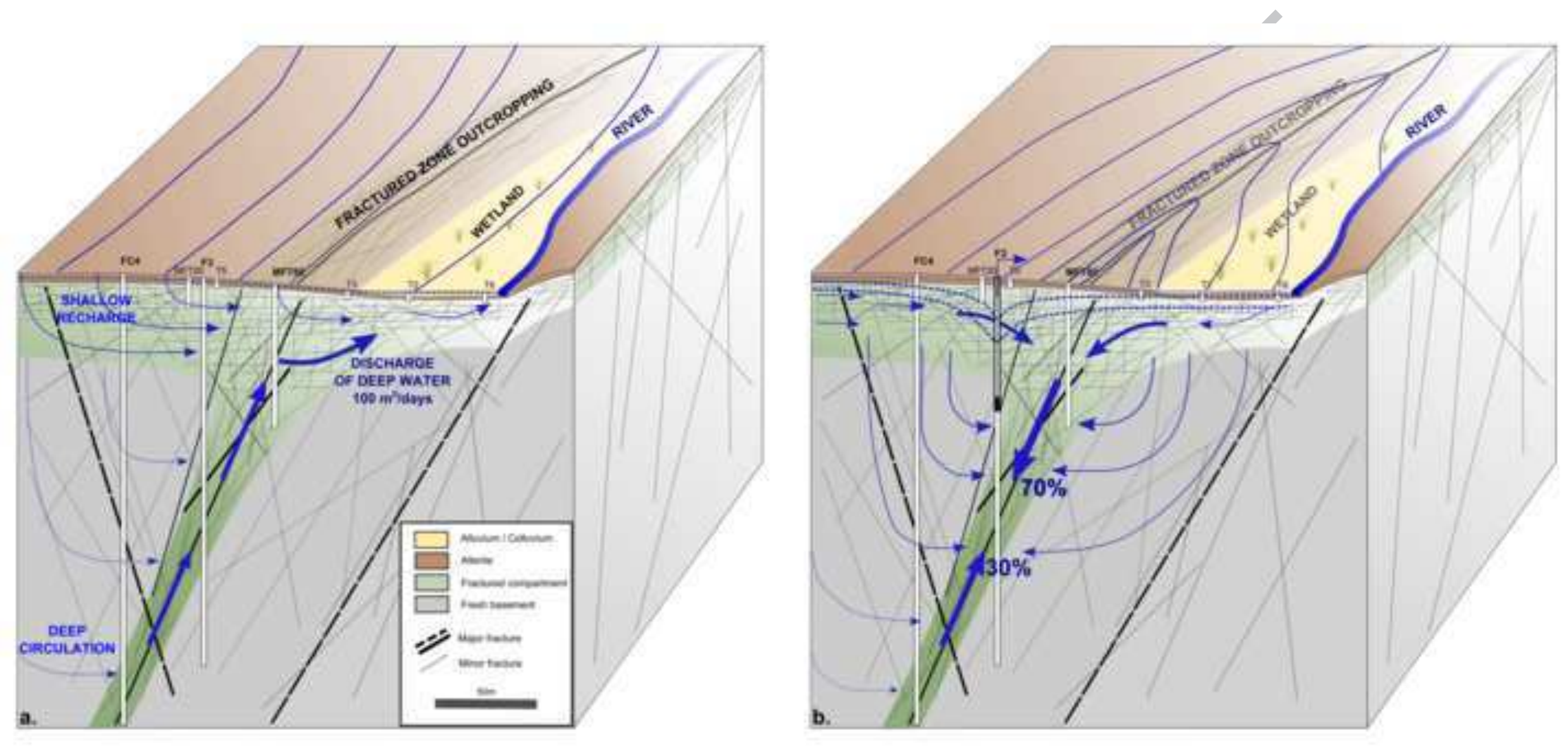

I.

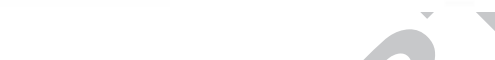




\begin{tabular}{|c|c|c|c|c|c|c|c|c|}
\hline & \multicolumn{7}{|c|}{ ACCEPTED MANUSCRIPT } & \multirow{2}{*}{ Main fracture depth (m) } \\
\hline & Well & $X$ (LAMB93) & Y (LAMB93) & $\mathrm{Z}$ (a.s.l.) & Depth $(\mathrm{m})$ & Geology & Slotted zone (m) & \\
\hline & F3 & 376280 & 6822515 & 93.53 & 216 & Brioverian bed rock & 30 to 216 & $110 ; 135 ; 160 ; 169 ; 180 ; 192$ \\
\hline & FC4 & 376252 & 6822521 & 95.1 & 250 & Brioverian bed rock & 40 to 250 & $160 ; 204 ; 235$ \\
\hline & MFT20 & 376286 & 6822500 & 93.68 & 20 & Brioverian bed rock & 10 to 20 & -2 \\
\hline & MFT80 & 376305 & 6822511 & 91.14 & 80 & Brioverian bed rock & 30 to 80 & $52 ; 69$ \\
\hline & $\mathrm{T} 1$ & 376350 & 6822537 & 88.22 & 6 & Alluvial deposits (wetland) & 1 to 6 & - \\
\hline & T2 & 376353 & 6822504 & 88.27 & 8 & Alluvial deposits (wetland) & 2 to 6 & - \\
\hline & T3 & 376329 & 6822490 & 89.57 & 6 & Alterites & 3 to 6 & - \\
\hline & T4 & 376255 & 6822496 & 95.55 & 8 & Alterites & 4 to 8 & - \\
\hline & T5 & 376294 & 6822485 & 93.54 & 7 & Alterites & 4 to 7 & - \\
\hline & T6 & 376314 & 6822530 & 89.63 & 7 & Alterites & 2 to 6.5 & - \\
\hline & T7 & 376273 & 6822531 & 93.02 & 9 & Alterites & 5 to 9 & - \\
\hline & T8 & 376389 & 6822521 & 88.06 & 3 & Alluvial deposits (wetland) & 0.5 to 3 & - \\
\hline
\end{tabular}




\begin{tabular}{cccccc} 
Well & $\begin{array}{c}\text { Depth of fault } \\
\text { zone }(\mathbf{m})\end{array}$ & $\begin{array}{c}\text { Ambient } \\
\text { Flowrate } \\
(\mathbf{L} / \mathbf{m n})\end{array}$ & $\begin{array}{c}\text { Total } \\
\text { transmissivity } \\
\left(\mathbf{m}^{2} / \mathbf{s}\right)\end{array}$ & $\begin{array}{c}\text { Fractured zone } \\
\text { transmissivity } \\
\left(\mathbf{m}^{2} / \mathbf{s}\right)\end{array}$ & $\begin{array}{c}\text { Part of total } \\
\text { productivity }\end{array}$ \\
\hline \hline FC4 & 235 & 3.5 & $1.3 \times 10^{-3}$ & $9.8 \times 10^{-4}$ & $75 \%$ \\
\hline F3 & $90-116$ & 3.5 & $1.8 \times 10^{-3}$ & $8.8 \times 10^{-4}$ & $50 \%$ \\
\hline MFT80 & $48-53$ & 2 & $7.9 \times 10^{-4}$ & $5.9 \times 10^{-4}$ & $75 \%$ \\
\hline
\end{tabular}




\begin{tabular}{ccccc} 
Well & SF6 (pptv) & CFC-12 (pptv) & CFC-11 (pptv) & CFC-113 (pptv) \\
\hline \hline F3 & 0 & 50.13 & 6.03 & 14.47 \\
\hline FC4 & 0 & 19.85 & 5.83 & 31.04 \\
\hline MFT20 & 0.87 & 48.29 & 6.64 & 21.48 \\
\hline MFT80 & 0.5 & 52.93 & 5.11 & 24.22 \\
\hline T's (mean) & 2.79 & 458.79 & 271.52 & 56.66 \\
\hline
\end{tabular}




\begin{tabular}{|c|c|c|c|c|c|c|c|c|c|}
\hline \multirow{2}{*}{ Wells } & \multirow{2}{*}{ Analytical models } & \multicolumn{2}{|c|}{ Fault aquifer } & \multicolumn{2}{|c|}{ Blocks parameters } & \multicolumn{3}{|c|}{ Superficial aquifer } & \multirow{2}{*}{$\begin{array}{c}\text { Error } \\
\text { RMSE [m] }\end{array}$} \\
\hline & & $T\left(m^{2} / s\right)$ & S (dless) & $\mathrm{Kb}(\mathrm{m} / \mathrm{s})$ & $\mathrm{Sb}(1 / \mathrm{m})$ & TO $\left(\mathrm{m}^{2} / \mathrm{s}\right)$ & Sy (dless) & $\mathrm{Kv}(\mathrm{m} / \mathrm{s})$ & \\
\hline \multirow{3}{*}{ F3 } & Moench early time & $7.00 \mathrm{E}-04$ & - & $2.47 \mathrm{E}-08$ & $2.62 \mathrm{E}-04$ & - & - & - & 0.98 \\
\hline & Hunt early time & $4.79 \mathrm{E}-04$ & - & - & - & $8.13 \mathrm{E}-05$ & $=1$ & - & 0.55 \\
\hline & Moench global & $1.05 \mathrm{E}-04$ & $7.00 \mathrm{E}-03$ & - & - & - & - & - & 0.95 \\
\hline \multirow{3}{*}{ MFT80 } & Moench early time & $7.38 \mathrm{E}-04$ & $7.00 \mathrm{E}-04$ & $1.34 \mathrm{E}-09$ & $1.15 \mathrm{E}-05$ & - & - & - & 0.59 \\
\hline & Hunt early time & $4.84 \mathrm{E}-04$ & $1.80 \mathrm{E}-03$ & - & - & $8.10 \mathrm{E}-05$ & 0.02 & $1.09 \mathrm{E}-07$ & 0.37 \\
\hline & Moench global & $9.03 \mathrm{E}-05$ & $1.75 E-03$ & $1.28 \mathrm{E}-08$ & $1.18 \mathrm{E}-03$ & +8 & - & - & 0.56 \\
\hline \multirow{3}{*}{ FC4 } & Moench early time & $6.25 \mathrm{E}-04$ & $8.40 \mathrm{E}-04$ & 8.47E-10 & $9.84 \mathrm{E}-06$ & - & - & - & 0.93 \\
\hline & Hunt early time & $3.87 \mathrm{E}-04$ & $1.61 \mathrm{E}-03$ & - & - & $6.94 \mathrm{E}-05$ & 0.02 & $8.00 \mathrm{E}-08$ & 0.21 \\
\hline & Moench global & $1.13 \mathrm{E}-04$ & $1.61 \mathrm{E}-03$ & $8.15 \mathrm{E}-09$ & $6.53 \mathrm{E}-04$ & - & - & - & 0.57 \\
\hline \multirow{3}{*}{ MFT20 } & Moench early time & $6.02 \mathrm{E}-04$ & $1.05 \mathrm{E}-02$ & $3.35 \mathrm{E}-08$ & $2.62 \mathrm{E}-04$ & - & - & - & 0.69 \\
\hline & Hunt early time & $7.27 \mathrm{E}-04$ & $1.17 \mathrm{E}-02$ & - & - & $5.79 \mathrm{E}-05$ & 0.05 & $8.04 \mathrm{E}-07$ & 0.19 \\
\hline & Moench global & $9.78 \mathrm{E}-05$ & $7.00 E-03$ & $6.33 E-08$ & $3.07 E-03$ & - & - & - & 0.57 \\
\hline
\end{tabular}


1 We propose hydrogeological conceptual model of fault aquifer in crystalline basement.

2 We characterize interactions between a fault aquifer and surrounding compartments.

3 Sub-vertical fault resource is strongly dependent on superficial aquifer storage.

4 We estimate groundwater resource availability. 


\section{ACCEPTED MANUSCRIPT}

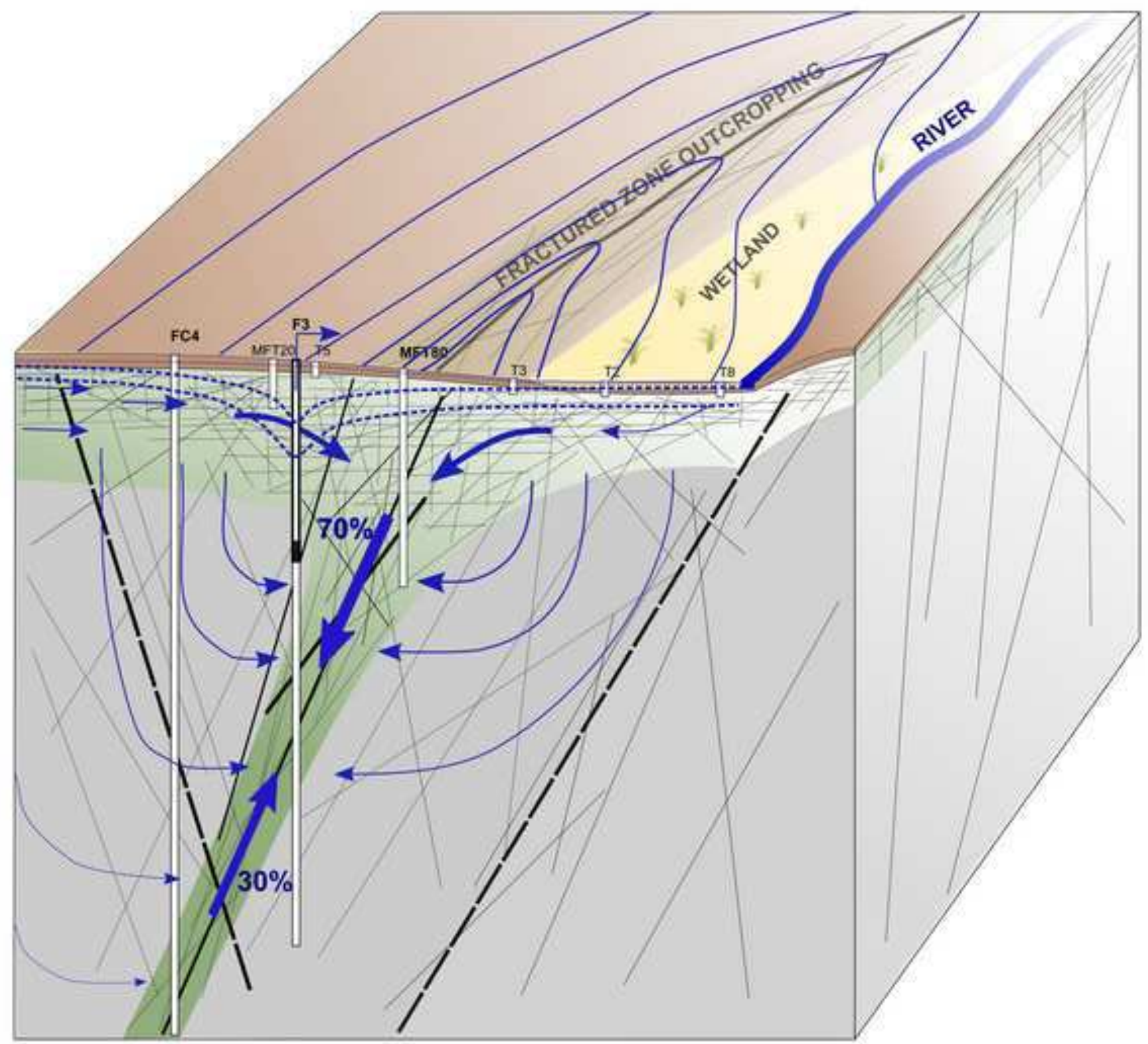

